\title{
Synthesis, Spectral Characterization and Antimicrobial Evaluation of New Metal Complexes of Novel Schiff Base Derived from 4,6-dihydroxy-1,3- phenylenediethanone
}

Yasmin mamdoh hussien Ahmed ( $\square$ yassmine@sci.cu.edu.eg )

Cairo University Faculty of Science https://orcid.org/0000-0001-6951-7735

Gehad G. Mohamed

Cairo University

\section{Research Article}

Keywords: Schiff base complexes, Antimicrobial activity, molecular docking, DFT

Posted Date: September 22nd, 2021

DOI: https://doi.org/10.21203/rs.3.rs-888707/v1

License: @ (i) This work is licensed under a Creative Commons Attribution 4.0 International License. Read Full License 


\section{Abstract}

A new tetradentate Schiff base ligand was prepared from condensation of 4,6-dihydroxy-1,3-

phenylenediethanone with ethane-1,2-diylbis(oxy)diethanamine. The ligand forms complexes in good yield. The Schiff base and its complexes were characterized by analytical (CHN elemental analyses, solubility, melting point, conductivity) measurements, spectral (IR, UV-vis, ${ }^{1} \mathrm{H}$ NMR and MS) and magnetic measurements. The elemental analyses, Uv-vis spectra, and room temperature magnetic moment data and theoretically through density function theory were used as characterizing techniques in supporting of further interpretation of the complexes structures. The results of elemental analyses, El-mass and conductivity measurements confirmed the stoichiometry of the ligand and its complexes while the characteristic absorption bands and resonance peaks in IR and NMR spectra confirmed the formation of the ligand frameworks around the metal ions. The octahedral environment for complexes derived from Schiff base ligand have been confirmed on the basis of results of electronic and diffused reflectance spectral studies and magnetic moment measurements. Detailed studies of the thermal properties of the Schiff base ligand and complexes were investigated by thermogravimetric technique. Moreover, the molecular docking into (PDB: 6NE0) was the DNA binding and supports the experimental finding and 6IY0 Crystal structure of conserved hypothetical protein SAV0927 from Staphylococcus aureus subsp. aureus Mu50. The synthesized ligand and its complexes were tested for in vitro antimicrobial activity against Candida albicans, Bacillus subtilis, Aspergillus flavus, Escherichia coli, Pseudomonas aeruginosa and Staphylococcus aureus by using agar-well diffusion method.

\section{Introduction}

The chemistry of the Schiff base ligands and their metal complexes has expanded enormously and encompasses a vast area of organometallic compounds and various aspects of bioinorganic chemistry [1]. The appearance of resistant bacteria reduces the efficiency of antimicrobial therapies, thereby increasing the need for more efficient drugs for infections treatment. Many studies showed an enhance in antimicrobial activity after the interaction of many agents with metal ions. Complexes of the metal ions with ligands which are polydentate have been the theme of demanding research as they have interesting spectral, magnetic properties and miscellaneous spectrum of biological activities.[2]

Imine (also known as Schiff base) compounds participate a function in inorganic chemistry as they can simply form stable complexes with the majority of transition metal ions. These are described by existence of azomethine group $(-\mathrm{N}=\mathrm{CHR})$ which was formed by condensation of carbonyl compound and primary amine (aldehydes or ketones).[2]

The flexibility of Schiff base ligands can be improved by hydrogenation of their $\mathrm{C}=\mathrm{N}$ bonds; they should thus coordinate metal ions more easily. For these reasons, reduced Schiff bases have recently gained considerable attention.[3]Various metal ions are widely recognized due to their significant roles in human Biological processes. a consequence of their nuclei size and electron availability to enhance interaction with organic molecules in biological systems. The presence of these metal ions results in premature aging and cell breakdown prevention.[4] 
The aim of the present study was to synthesize and characterize metal complexes with newly synthesized Schiff base ligand. The work is supported by density functional theory (DFT) and molecular docking studies. The binding affinity is confirmed by docking Schiff base ligand with 6 NEO and 6iy 0 proteins. The activity predictions were conducted using Hex scores for ligand and its metal complexes. The theoretical studies undertaken strengthen the experimental results. The Schiff base ligand and metal complexes were assayed for antibacterial activities against Gram positive (Bacillus subtilis, Staphylococcus aureus, and Streptococcus faecalis) and Gram negative bacterial strains (Escherichia coli, Pseudomonas aeruginosa, and Enterobacter cloacae) by disc diffusion method. Most complexes show potent antibacterial activity against the six bacterial strains. The results of this study may be useful to understand antimicrobial activity of metal(II)/(III) complexes with Schiff base ligand and metal complexes.

\subsubsection{Molecular Docking}

\subsubsection{Target Selection and Preparation}

The key step in drug design and development is the ability to identify and select the appropriate drug target(s). We have identified and selected the following drug targets (shown in Fig. 9); PDB code: 6NE0 Structure of double-stranded target DNA engaged Csy complex from Pseudomonas aeruginosa (PA-14) antimicrobial activities of our compounds and 6IY0 Crystal structure of conserved hypothetical protein SAV0927 from Staphylococcus aureus subsp. aureus Mu50. They were loaded from protein data (http:// http://www.rcsb.org./pdb). Discovery studio was used to prepare the proteins for docking. The energy of the protein molecules and the coordination compounds were minimized using the Energy minimization algorithm of Molecular Operating Environment (MOE2008 software). The binding of the ligand molecule with the protein molecule was analyzed using MOE docking program to find the correct conformation (with the rotation of bonds, structure of molecule is not rigid).[5]

\section{Instrumentation}

Microanalyses of carbon, hydrogen and nitrogen were carried out at the Microanalytical Center, Cairo University, Egypt, using a CHNS-932 (LECO) Vario elemental analyzer. Analyses of the metals were performed by dissolving the solid complexes in concentrated $\mathrm{HNO}_{3}$ and dissolving the remainder in deionized water. The metal content was carried out using inductively coupled plasma atomic absorption spectrometry (ICP-AES), Egyptian Petroleum Research Institute. Fourier transform infrared (FT-IR) spectra were recorded with a PerkinElmer 1650 spectrometer $\left(400-4000 \mathrm{~cm}^{-1}\right)$ as $\mathrm{KBr}$ pellets. ${ }^{1} \mathrm{H}$ NMR spectra, as solutions in DMSO-d6, were chronicled with a $300 \mathrm{MHz}$ Varian-Oxford Mercury at room temperature using tetra-methylsilane as an interior standard. Mass spectra were chronicled using the electron ionization technique at $70 \mathrm{eV}$ with an MS-5988 GSMS Hewlett- Packard instrument at the Microanalytical Center, National Center for Research, Egypt. UV-visible spectra were acquired with a Shimadzu UVmini-1240 spectrophotometer. Molar conductivities of $10^{-3} \mathrm{M}$ solutions of the solid complexes in DMF were measured with a Jenway 4010 conductivity meter. Thermogravimetric (TG) and differential thermogravimetric (DTG) analyses of the solid complexes were carried out from room temperature to 1000 ॰C using a Shimadzu TG-50H thermal analyzer. Antimicrobial measurements were carried out at the Microanalytical Center, Cairo University, Egypt. Anticancer activity 
experiments were performed at the National Cancer Institute, Cancer Biology Department, Pharmacology Department, Cairo University. The optical density (OD) of each in good form was measured spectrophotometrically at $564 \mathrm{~nm}$ with an ELIZA microplate reader (Meter tech. R960, Lewiston, USA). The Xray diffraction (XRD) was recorded by Bruker D8 Discover (Bruker AXS Inc., 35 KV, 30 mA) X-ray diffractometer in Egypt Nanotechnology Center (EGNC), with a step size of 0.02 and speed scan 0.016 using Cu Ka radiation $(\lambda=1.5406 \AA)$.

\section{Pharmacology}

\section{Antibacterial activities}

Antimicrobial activity of the tested samples was determined by a modified Kirby-Bauer disc diffusion method. [6] Briefly, $100 \mu \mathrm{l}$ of the test bacteria were grown in $10 \mathrm{ml}$ of fresh media until they reached a count of approximately $108 \mathrm{cells} / \mathrm{ml}$ for bacteria. $100 \mu \mathrm{l}$ of microbial suspension was spread onto agar plates corresponding to the broth in which they were maintained. Isolated colonies of each organism that may be playing a pathogenic part should be selected from primary agar plates and tested for susceptibility by disc diffusion method. Plates inoculated Gram(+) bacteria as Staphylococcus aureus and Gram(-) bacteria as Escherichia coli. They were incubated at $35-37^{\circ} \mathrm{C}$ for $24-48 \mathrm{~h}$ and yeast as Candida albicans incubated at $30{ }^{\circ} \mathrm{C}$ for 24-48 hours and, then the diameters of the inhibition zones were measured in millimeters then the diameters of the inhibition zones were calculated in millimeters. Standard discs of amikacin (antibacterial agent), served as positive controls for antimicrobial activity but filter discs impregnated with $10 \mu$ l of solvent (distilled water, chloroform, DMSO) were used as a negative control. Blank paper disks (Schleicher \& Schuell, Satis Lda, Spain) with a diameter of $8.0 \mathrm{~mm}$ were impregnated with $10 \mu$ of tested concentration of the stock solutions $(20 \mathrm{mg} / \mathrm{ml})$. When a filter paper disc impregnated with a tested chemical is placed on agar, the chemical will diffuse from the disc into the agar. This diffusion will place the chemical in the agar only around the disc. The solubility of the chemical and its molecular size will determine the size of the area of chemical infiltration around the disc. If an organism is placed on the agar it will not grow in the area around the disc if it is susceptible to the chemical. This area of no growth around the disc is known as a zone of inhibition or Clear zone. For the disc diffusion, the zone diameters were measured with slipping calipers of the National Committee for Clinical Laboratory Standards. Agar-based methods such as E-test and disk diffusion can be good alternatives because they are easier and more rapidly than broth-based methods.

\section{Computational methodology}

Gaussian09 suite of program was designed for the electronic structure calculations for $\mathrm{H}_{2} \mathrm{~L}$ and $\mathrm{Cu}$ (II) complex. DFT based B3LYP method along by the LANL2DZ basis regulate was employed for full optimization. In order to assimilate the effect of the solvent around the molecule, the TDDFT method (along with LANL2DZ basic set) was used to calculate the electronic absorption spectra of the ligand and its $\mathrm{Cu}$ (II) complex.

\section{Results And Discussion}

The structures of the synthesized Schiff base ligand and its metal complexes are given in Figs. 1 and 3 . The compounds on physicochemical basis remained non-hygroscopic, unchanging at room temperature, mostly insoluble in water, ethanol, methanol fairly soluble in dimethylformamide and then equitably soluble in 
dimethyl-sulphoxide. Though, the analytical figures indicated 1:1 molar ratio of metal-to-ligand for the metal complexes systems and different shades of colors in expectedly good yields (80.0-83.0\%) and were displayed by the compounds synthesized, which were completely different from their precursors. Elemental analyses results for the synthesized compounds in combination with the percentage metal compositions in the metal complexes revealed good agreement among the experimental and theoretical data (Table 1). The Schiff base and its metal complexes showed sharp and higher melting points with distinct deviation from that of the precursors. The Schiff base melted at $>300^{\circ} \mathrm{C}$ while its metal complexes had high melting points ranged from $149{ }^{\circ} \mathrm{C}$ to $>300{ }^{\circ} \mathrm{C}$.[4]

Table 1

Analytical and physical data of Schiff base ligand $\left(\mathrm{H}_{2} \mathrm{~L}\right)$ and its metal complexes.

\begin{tabular}{|c|c|c|c|c|c|c|c|c|}
\hline \multirow{2}{*}{$\begin{array}{l}\text { Compound } \\
\text { (Molecular } \\
\text { Formula) }\end{array}$} & \multirow{2}{*}{$\begin{array}{l}\text { Colour } \\
\text { (\%yield) }\end{array}$} & \multirow{2}{*}{$\begin{array}{l}\text { M.p. } \\
\left({ }^{\circ} \mathrm{C}\right)\end{array}$} & \multicolumn{4}{|c|}{ \% Found (Calcd.) } & \multirow{2}{*}{$\begin{array}{l}\Lambda_{\mathrm{m}} \\
\Omega^{-1} \mathrm{~mol}^{-1} \\
\mathrm{~cm}^{2}\end{array}$} & \multirow{2}{*}{$\begin{array}{l}\mu_{\text {eff }} \\
\text { (BM) }\end{array}$} \\
\hline & & & C & H & $\mathbf{N}$ & $M$ & & \\
\hline $\mathrm{H}_{2} \mathrm{~L}$ & $\begin{array}{l}\text { yellow } \\
\text { (92) }\end{array}$ & $\begin{array}{l}> \\
300\end{array}$ & $\begin{array}{l}62.41 \\
(62.67)\end{array}$ & $\begin{array}{l}6.79 \\
(7.18)\end{array}$ & $\begin{array}{l}9.02 \\
(9.14)\end{array}$ & - & - & - \\
\hline $\begin{array}{l}{\left[\mathrm{Cr}\left(\mathrm{H}_{2} \mathrm{~L}\right)\right.} \\
\left.\left(\mathrm{H}_{2} \mathrm{O}\right) \mathrm{Cl}\right] \mathrm{Cl}_{2} \cdot 3 \mathrm{H}_{2} \mathrm{O}\end{array}$ & $\begin{array}{l}\text { black } \\
(83)\end{array}$ & 300 & $\begin{array}{l}35.23 \\
(35.76)\end{array}$ & $\begin{array}{l}5,34 \\
(5.59)\end{array}$ & $\begin{array}{l}5.00 \\
(5.22)\end{array}$ & $\begin{array}{l}9.47 \\
(9.69)\end{array}$ & 103 & 3.72 \\
\hline $\begin{array}{l}{\left[\mathrm{Mn}\left(\mathrm{H}_{2} \mathrm{~L}\right)\right.} \\
\left.\left(\mathrm{H}_{2} \mathrm{O}\right)_{2}\right] \mathrm{Cl}_{2} \cdot 2 \mathrm{H}_{2} \mathrm{O}\end{array}$ & $\begin{array}{l}\text { black } \\
\text { (81) }\end{array}$ & 204 & $\begin{array}{l}37.88 \\
(38.07)\end{array}$ & $\begin{array}{l}5.79 \\
(5.95)\end{array}$ & $\begin{array}{l}5.20 \\
(5.55)\end{array}$ & $\begin{array}{l}10.39 \\
(10.90)\end{array}$ & 104 & 4.97 \\
\hline $\begin{array}{l}{\left[\mathrm{Fe}\left(\mathrm{H}_{2} \mathrm{~L}\right) \mathrm{Cl}\right.} \\
\left.{ }_{2}\right] \mathrm{Cl} 2 \mathrm{H}_{2} \mathrm{O}\end{array}$ & $\begin{array}{l}\text { Dark } \\
\text { brown } \\
(83)\end{array}$ & $\overrightarrow{300}$ & $\begin{array}{l}38.00 \\
(38.03)\end{array}$ & $\begin{array}{l}5.02 \\
(5.15)\end{array}$ & $\begin{array}{l}5.19 \\
(5.55)\end{array}$ & $\begin{array}{l}10.56 \\
(11.09)\end{array}$ & 90 & 5.19 \\
\hline $\begin{array}{l}{\left[\mathrm{Co}\left(\mathrm{H}_{2} \mathrm{~L}\right)\right.} \\
\left.\left(\mathrm{H}_{2} \mathrm{O}\right)_{2}\right] \mathrm{Cl}_{2} \cdot \mathrm{H}_{2} \mathrm{O}\end{array}$ & $\begin{array}{l}\text { black } \\
(82)\end{array}$ & 184 & $\begin{array}{l}38.77 \\
(39.15)\end{array}$ & $\begin{array}{l}5.37 \\
(5.71)\end{array}$ & $\begin{array}{l}5.60 \\
(5.71)\end{array}$ & $\begin{array}{l}12.41 \\
(12.03)\end{array}$ & 115 & 5.48 \\
\hline $\begin{array}{l}{\left[\mathrm{Ni}\left(\mathrm{H}_{2} \mathrm{~L}\right)\left(\mathrm{H}_{2} \mathrm{O}\right)\right.} \\
\mathrm{Cl}] \mathrm{Cl} .3 \mathrm{H}_{2} \mathrm{O}\end{array}$ & $\begin{array}{l}\text { black } \\
(80)\end{array}$ & $\begin{array}{l}> \\
300\end{array}$ & $\begin{array}{l}37.73 \\
(37.77)\end{array}$ & $\begin{array}{l}5.42 \\
(5.90)\end{array}$ & $\begin{array}{l}5.24 \\
(5.51)\end{array}$ & $\begin{array}{l}11.28 \\
(11.54)\end{array}$ & 62 & 3.43 \\
\hline$\left[\mathrm{Cu}\left(\mathrm{H}_{2} \mathrm{~L}\right) \mathrm{Cl}_{2}\right] 4 \mathrm{H}_{2} \mathrm{O}$ & $\begin{array}{l}\text { black } \\
(83)\end{array}$ & 187 & $\begin{array}{l}37.22 \\
(37.43)\end{array}$ & $\begin{array}{l}5.61 \\
(5.85)\end{array}$ & $\begin{array}{l}5.40 \\
(5.55)\end{array}$ & $\begin{array}{l}11.37 \\
(12.38)\end{array}$ & 35 & 1.80 \\
\hline$\left[\mathrm{Zn}\left(\mathrm{H}_{2} \mathrm{~L}\right) \mathrm{Cl}_{2}\right] 2 \mathrm{H}_{2} \mathrm{O}$ & $\begin{array}{l}\text { black } \\
(80)\end{array}$ & 149 & $\begin{array}{l}40.00 \\
(40.13)\end{array}$ & $\begin{array}{l}5.18 \\
(5.43)\end{array}$ & $\begin{array}{l}5.28 \\
(5.85)\end{array}$ & $\begin{array}{l}19.19 \\
(13.67)\end{array}$ & 38 & Diamagnetic \\
\hline$\left[\mathrm{Cd}\left(\mathrm{H}_{2} \mathrm{~L}\right) \mathrm{Cl}_{2}\right] \mathrm{H}_{2} \mathrm{O}$ & $\begin{array}{l}\text { brown } \\
\text { (82) }\end{array}$ & 231 & $\begin{array}{l}37.70 \\
(37.81)\end{array}$ & $\begin{array}{l}4.65 \\
(4.73)\end{array}$ & $\begin{array}{l}5.32 \\
(5.51)\end{array}$ & $\begin{array}{l}22.00 \\
(22.14)\end{array}$ & 29 & Diamagnetic \\
\hline
\end{tabular}




\section{IR spectra}

The IR spectra of Schiff base ligand and its metal complexes were represented in Table 2. The IR spectrum of the prepared ligand, which showed a strong band at 1600

Table 2

IR spectra of $\mathrm{H}_{2} \mathrm{~L}$ ligand and its metal complexes.

\begin{tabular}{|c|c|c|c|c|c|c|}
\hline Assignment & $\begin{array}{l}\mathrm{v}(\mathrm{OH}) \\
\text { phenolic and } \\
\mathrm{H}_{2} \mathrm{O}\end{array}$ & $\begin{array}{l}\mathrm{v}(\mathrm{C}=\mathrm{N}) \\
\text { azomethine }\end{array}$ & $V(C-0)$ & $\begin{array}{l}\rho r\left(\mathrm{H}_{2} \mathrm{O}\right) \text { and } \\
\rho w\left(\mathrm{H}_{2} \mathrm{O}\right) .\end{array}$ & $\begin{array}{l}\mathrm{v}(\mathrm{M}- \\
0)\end{array}$ & $\begin{array}{l}\mathrm{v}(\mathrm{M}- \\
\mathrm{N})\end{array}$ \\
\hline $\mathrm{H}_{2} \mathrm{~L}$ & $3424 \mathrm{br}$ & 1600sh & $1128 \mathrm{sh}$ & - & - & - \\
\hline $\begin{array}{l}{\left[\mathrm{Cr}\left(\mathrm{H}_{2} \mathrm{~L}\right)\right.} \\
\left.\left(\mathrm{H}_{2} \mathrm{O}\right) \mathrm{Cl}\right] \mathrm{Cl}_{2} \cdot 3 \mathrm{H}_{2} \mathrm{O}\end{array}$ & $3432 \mathrm{br}$ & $1606 \mathrm{sh}$ & $1118 \mathrm{~m}$ & 816,697 & 565 & 448 \\
\hline $\begin{array}{l}{\left[\mathrm{Mn}\left(\mathrm{H}_{2} \mathrm{~L}\right)\right.} \\
\left.\left(\mathrm{H}_{2} \mathrm{O}\right)_{2}\right] \mathrm{Cl}_{2} \cdot 2 \mathrm{H}_{2} \mathrm{O}\end{array}$ & $3405 \mathrm{br}$ & 1634 sh & $1102 s$ & 873,620 & 579 & 414 \\
\hline$\left[\mathrm{Fe}\left(\mathrm{H}_{2} \mathrm{~L}\right) \mathrm{Cl}_{2}\right] \mathrm{Cl} 2 \mathrm{H}_{2} \mathrm{O}$ & $3432 \mathrm{br}$ & $1622 m$ & $1106 \mathrm{~s}$ & 841,670 & 579 & 445 \\
\hline $\begin{array}{l}{\left[\mathrm{Co}\left(\mathrm{H}_{2} \mathrm{~L}\right)\right.} \\
\left.\left(\mathrm{H}_{2} \mathrm{O}\right)_{2}\right] \mathrm{Cl}_{2} \cdot \mathrm{H}_{2} \mathrm{O}\end{array}$ & $3430 \mathrm{br}$ & 1633sh & $1115 \mathrm{~s}$ & 838,666 & 578 & 431 \\
\hline $\begin{array}{l}{\left[\mathrm{Ni}\left(\mathrm{H}_{2} \mathrm{~L}\right)\left(\mathrm{H}_{2} \mathrm{O}\right)\right.} \\
\text { Cl]Cl. } 3 \mathrm{H}_{2} \mathrm{O}\end{array}$ & $3402 \mathrm{br}$ & 1623sh & $1119 \mathrm{~s}$ & 837,665 & 563 & 423 \\
\hline$\left[\mathrm{Cu}\left(\mathrm{H}_{2} \mathrm{~L}\right) \mathrm{Cl}_{2}\right] 4 \mathrm{H}_{2} \mathrm{O}$ & $3438 \mathrm{br}$ & $1622 m$ & $1132 m$ & 769,666 & 534 & 445 \\
\hline$\left[\mathrm{Zn}\left(\mathrm{H}_{2} \mathrm{~L}\right) \mathrm{Cl}_{2}\right] 2 \mathrm{H}_{2} \mathrm{O}$ & $3432 \mathrm{br}$ & 1632sh & 1115sh & 875,602 & 580 & 417 \\
\hline$\left[\mathrm{Cd}\left(\mathrm{H}_{2} \mathrm{~L}\right) \mathrm{Cl}_{2}\right] \mathrm{H}_{2} \mathrm{O}$ & $3428 \mathrm{br}$ & 1630sh & 1113sh & 770,611 & 520 & 416 \\
\hline
\end{tabular}

$\mathrm{cm}^{-1}$, was assigned to the azomethine $(\mathrm{C}=\mathrm{N})$ group. This band was shifted to a higher frequency (1606$\left.1634 \mathrm{~cm}^{-1}\right)$ in the complexes [8]. This shift indicates coordination of the azomethine nitrogen to the metal ions in the complexes. Also, $\mathrm{OH}$ stretching vibration band found at $3424 \mathrm{~cm}^{-1}$ in the free ligand was appeared as broad band in the range of $3402-3438 \mathrm{~cm}^{-1}$ in the spectra of metal complexes which assigned to $\mathrm{VOH}$ group and water molecules, $\mathrm{v}\left(\mathrm{H}_{2} \mathrm{O}\right)$ associated with the complexes. Coordinated water molecules exhibited $\operatorname{pr}\left(\mathrm{H}_{2} \mathrm{O}\right)$ rocking vibration in the range of $769-875 \mathrm{~cm}^{-1}$ and $\rho w\left(\mathrm{H}_{2} \mathrm{O}\right)$ wagging vibration near $602-697 \mathrm{~cm}^{-1}$ [7] [8]. The etheric $v(C-0)$ stretching vibration band is observed at $1128 \mathrm{~cm}^{-1}$ in the free ligand. By comparing the IR spectra of metal complexes with the spectrum of the free ligand, this band was found in the spectra of the complexes at $1102-1132 \mathrm{~cm}^{-1}$ confirming the participation of etheric oxygen atoms in complex 
formation. However, two new bands in the range of 520-580 and 414- $448 \mathrm{~cm}^{-1}$ were also observed (Table 2). These two bands were observed in the complexes and not found in the spectrum of the free ligand and they are attributed to $\mathrm{M}-\mathrm{O}$ and $\mathrm{M}-\mathrm{N}$ bonds in the complexes, respectively.[1]

Consequently, the IR spectra illustrated a tetradentate ligand that coordinates through two etheric oxygen atoms and two imino nitrogen atoms from azomethine group. The coordination sphere of the metal is completed by the water molecules and chloride atoms and its mononuclear metal complexes are given in the experimental part.

\section{H NMR Spectra}

The ${ }^{1} \mathrm{H}$ NMR spectra have been recorded for Schiff base ligand, Cd(II) and Zn(II) complexes (Table 3). In the spectra of complexes, a shift of electron density from the ligand to metal had been observed. The $\mathrm{OH}$ protons for Schiff base ligand appeared at 16.96 ppm was found in the complexes at 16.95 and 16.94 ppm in the $\mathrm{Zn}$ (II) and Cd(II) complexes. Respectively. This region of the hydroxyl proton confirming coordination of oxygen to the central metal atom not occur. In the spectrum of Schiff base ligand, two singlet signals at 7.56 and $8.44 \mathrm{ppm}$ were assigned to the aromatic protons. These singlet signals were slightly shifted upon coordination as showed in Table 3. Protons of Schiff base ligand appeared at $\delta 2.26-2.88 \mathrm{ppm}\left(-\mathrm{CH}_{3}\right)$ and at 83.22-3.69 ppm $\left(-\mathrm{CH}_{2}-\right)$. These signals showed a slight shift upon coordination with metal ions. In the spectra of $\mathrm{Cd}(\mathrm{II})$ and $\mathrm{Zn}(\mathrm{II})$ complexes, a singlet at 2.32-2.51 ppm and 2.31-2.98 ppm was due to $\left(-\mathrm{CH}_{3}\right)$ groups and a singlet at 3.32-3.59 and 3.13-3.81 ppm was due to $\left(-\mathrm{CH}_{2}\right)$ groups [9][10] [11]. 
Table 3

The ${ }^{1}$ H-n.m.r. chemical shifts (d; p.p.m.) of the Schiff base, and its complexes in DMSO-d6 and their assignments

\begin{tabular}{|c|c|c|}
\hline Compound & Chemical shift ( $\delta)$ ppm & Assignments \\
\hline \multirow{4}{*}{$\mathrm{H}_{2} \mathrm{~L}$} & 16.96 & {$[\mathrm{~s}, 2 \mathrm{H}, 2 \mathrm{OH}]$} \\
\hline & $7.56,8.44$ & {$[\mathrm{D}, 2 \mathrm{H}, 2 \mathrm{Ar}-\mathrm{H}]$} \\
\hline & $2.26-2.88$ & {$\left[\mathrm{M}, 6 \mathrm{H}, 2 \mathrm{CH}_{3}\right]$} \\
\hline & $3.22-3.69$ & {$\left[\mathrm{M}\right.$, three $\left(-\mathrm{CH}_{2}-\mathrm{CH}_{2}-\right.$ groups] } \\
\hline \multirow[t]{4}{*}[\mathrm{Zn}(\mathrm{H}_{2}\mathrm{L})\mathrm{Cl}_{2}]{$2 \mathrm{H}_{2} \mathrm{O}$} & 16.94 & {$[\mathrm{~s}, 2 \mathrm{H}, 2 \mathrm{OH}]$} \\
\hline & $7.95-8.14$ & {$[\mathrm{M}, 7 \mathrm{H}, 7 \mathrm{Ar}-\mathrm{H}]$} \\
\hline & $2.31-2.98$ & {$\left[\mathrm{M}, 12 \mathrm{H}, 4 \mathrm{CH}_{3}\right]$} \\
\hline & $3.13-3.81$ & {$\left[\mathrm{M}\right.$, three $\left(-\mathrm{CH}_{2}-\mathrm{CH}_{2}-\right.$ groups] } \\
\hline \multirow[t]{4}{*}[\mathrm{Cd}(\mathrm{H}_{2}\mathrm{L})\mathrm{Cl}_{2}]{$\mathrm{H}_{2} \mathrm{O}$} & 16.95 & {$[\mathrm{~s}, 2 \mathrm{H}, 2 \mathrm{OH}] \mathrm{a}$ and $\mathrm{b}$} \\
\hline & $8.00,8.21$ & {$[\mathrm{D}, 2 \mathrm{H}, 2 \mathrm{Ar}-\mathrm{H}]$} \\
\hline & $2.32-2.51$ & {$\left[\mathrm{M}, 6 \mathrm{H}, 2 \mathrm{CH}_{3}\right]$} \\
\hline & $3.32-3.59$ & {$\left[\mathrm{M}\right.$, three $\left(-\mathrm{CH}_{2}-\mathrm{CH}_{2}-\right.$ groups] } \\
\hline
\end{tabular}

\section{Molar conductance}

The molar conductivity $\left(\Lambda_{m}\right)$ of the metal complexes was determined by applying the relation $\Lambda_{m}=1000 \times \mathrm{K} / \mathrm{c}$, where $\mathrm{k}$ and $\mathrm{c}$ stands for the specific conductance and molar concentration of metal complexes, respectively. The complexes were dissolved in DMF and their conductivity were measured at room temperature. The molar conductivity data were observed as 103, 104, 90, 115 and $62 \mathrm{~S} \mathrm{~cm}^{-1} \mathrm{~mol}^{-1}$ for $\mathrm{Cr}(\mathrm{III}), \mathrm{Mn}$ (II), Fe(III), Co(II) and $\mathrm{Ni}(\mathrm{II})$, respectively, indicating their electrolytic nature and as 35, 38 and 29

$\mathrm{S} \mathrm{cm}^{-1} \mathrm{~mol}^{-1}$ for the $\mathrm{Cu}(\mathrm{II}), \mathrm{Zn}(\mathrm{II})$ and $\mathrm{Cd}(\mathrm{II})$ complexes, respectively, indicating their non -electrolytic nature [12].

\section{Mass spectral study}

Mass spectrometry has been successfully used to investigate molecular structure of complexes. This method is particularly useful when a poorly crystalline nature of complexes prevents their X-ray characterization. The pattern of mass spectrum (Fig. 2a-b) gives an impression of the successive degradation of the target compound with the series of peaks corresponding to the various fragments. Their intensity gives an idea of stability of fragments. The recorded molecular ion peaks of the metal complexes have been used to confirm 
the proposed formula.[3] Mass spectrum of Schiff base ligand and its $\mathrm{Zn}$ (II) complex is carried out to determine its molecular weight and fragmentation pattern as explained in Table 4 [13].

Table 4

The fragmentation data for the $\mathrm{H}_{2} \mathrm{~L}$ and its $\mathrm{Zn}$ (II) complex

\begin{tabular}{|llll|}
\hline Ligand & Assignments & Peak m/z & calculation \\
\hline $\mathrm{H}_{2} \mathrm{~L}$ & $\mathrm{M}=\left(\mathrm{C}_{16} \mathrm{H}_{22} \mathrm{~N}_{2} \mathrm{O}_{4}\right)$ & 307.01 & 306.39 \\
& $\mathrm{M}-\mathrm{C} 3 \mathrm{NO}=\mathrm{M} 1$ & 240.10 & 240.39 \\
& $\mathrm{M} 1-\mathrm{CNOH} 4=\mathrm{M} 2$ & 194.05 & 194.39 \\
& $\mathrm{M} 2-\mathrm{C} 6 \mathrm{H} 3=\mathrm{M} 3$ & 119.10 & 119.39 \\
& $\mathrm{M} 3-\mathrm{C} 2 \mathrm{H} 6=\mathrm{M} 4$ & 89.10 & 89.39 \\
& $\mathrm{M} 4-\mathrm{C} 2 \mathrm{H} 4=\mathrm{M} 5$ & 61.05 & 61.39 \\
\hline $\left.\mathrm{Zn}\left(\mathrm{H}_{2} \mathrm{~L}\right) \mathrm{Cl}_{2}\right] 2 \mathrm{H}_{2} \mathrm{O}$ & $\mathrm{M}=\left(\mathrm{ZnC}_{16} \mathrm{H}_{26} \mathrm{~N}_{2} \mathrm{O}_{6} \mathrm{Cl}_{2}\right)$ & 479.00 & 478.78 \\
& $\mathrm{M}-\mathrm{Zn} \mathrm{H}_{4} \mathrm{O}_{2} \mathrm{Cl}_{2}=\mathrm{M} 1$ & 306.20 & 306.39 \\
& $\mathrm{M} 1-\mathrm{C}_{4} \mathrm{~N}_{2} \mathrm{O}_{2} \mathrm{H}_{4}=\mathrm{M} 2$ & 194.10 & 194.39 \\
& $\mathrm{M} 2-\mathrm{C}_{7} \mathrm{OH}_{3}=\mathrm{M} 3$ & 91.00 & 91.39 \\
$\mathrm{M} 3-\mathrm{CH}_{2}=\mathrm{M} 4$ & 77.00 & 77.39 \\
\hline
\end{tabular}

\section{Electronic spectral and magnetic moments}

The UV-Visible spectrum of Schiff base ligand in DMF appeared two absorption bands at $262 \mathrm{~nm}$ which is due to $\pi \rightarrow \pi^{\star}$ transition and a broad low intensity band at $547 \mathrm{~nm}$ which had been related to $n \rightarrow \pi^{\star}$ transition. The spectral properties of the metal complexes showed bathochromic shifts of ligand band. The bands assigned to intraligand $\pi \rightarrow \pi^{*}$ for the $\mathrm{Cr}(\mathrm{III}), \mathrm{Mn}(\mathrm{II}), \mathrm{Fe}(\mathrm{III}), \mathrm{Co}(\mathrm{II}), \mathrm{Ni}(\mathrm{II}), \mathrm{Cu}(\mathrm{II}), \mathrm{Zn}(\mathrm{II})$ and $\mathrm{Cd}(\mathrm{II})$ complexes were observed at 278, 265, 263, 265, 264, 263, 262 and $267 \mathrm{~nm}$, respectively [14][15].

The diffused reflectance spectrum of the $\mathrm{Cr}$ (III) complex displayed three absorption bands at 25,641, 25,000 and $18,281 \mathrm{~cm}^{-1}$ assignable to ${ }^{4} \mathrm{~A}_{2} \mathrm{~g} \rightarrow{ }^{4} \mathrm{~T}_{2} \mathrm{~g},{ }^{4} \mathrm{~A}_{2} \mathrm{~g} \rightarrow{ }^{4} \mathrm{~T}_{1} \mathrm{~g}(\mathrm{f})$ and ${ }^{4} \mathrm{~A}_{2} \mathrm{~g} \rightarrow{ }^{4} \mathrm{~T}_{1} \mathrm{~g}(\mathrm{p})$ transitions, respectively. The magnetic moment of the solid $\mathrm{Cr}$ (III) complex is 3.72 B.M., which confirms the high spin octahedral geometry around the $\mathrm{Cr}(\mathrm{III})$ ion.[16]

The diffused reflectance spectrum of the Mn(II) complex showed three bands at 33,333, 27,397 and 24,390 $\mathrm{cm}^{-1}$ which attributed to ${ }^{6} \mathrm{~A}_{1} \mathrm{~g} \rightarrow{ }^{4} \mathrm{Eg}(\mathrm{D}),{ }^{6} \mathrm{~A}_{1} \mathrm{~g} \rightarrow{ }^{4} \mathrm{~T}_{1} \mathrm{~g}(\mathrm{P}),{ }^{6} \mathrm{~A}_{1} \mathrm{~g} \rightarrow{ }^{4} \mathrm{~T}_{2} \mathrm{~g}(\mathrm{D})$ and ${ }^{6} \mathrm{~A}_{1} \mathrm{~g} \rightarrow{ }^{4} \mathrm{~A}_{1} \mathrm{~g}(\mathrm{G})$ transitions, respectively. This data consistent with a high spin $\mathrm{d}^{5}$ octahedral system. The complex was found to have magnetic moment value of 4.97 B.M., thus, it assumed to has an octahedral geometry.[17] 
The diffused reflectance spectrum of the brown Fe(III) complex exhibits two peaks at 27,777 and $29,585 \mathrm{~cm}^{-1}$ assigned to the $d-d$ transitions of the type ${ }^{6} A_{1} g \rightarrow{ }^{4} T_{2} g$ and ${ }^{6} A_{1} g \rightarrow{ }^{4} T_{2} g$, respectively. The complex was found to has magnetic susceptibility value of 5.19 suggesting an octahedral symmetry around the $\mathrm{Fe}(\mathrm{III})$ ion. [16]

The diffused reflectance spectrum of Co(II) complex showed three broad peaks at 15,408, 16,420 and 18,281 $\mathrm{cm}^{-1}$ assigned to ${ }^{4} \mathrm{~T}_{1} \mathrm{~g} \rightarrow{ }^{4} \mathrm{~T}_{2} \mathrm{~g}(\mathrm{~F}),{ }^{4} \mathrm{~T}_{1} \mathrm{~g} \rightarrow{ }^{4} \mathrm{~A}_{2} \mathrm{~g}(\mathrm{~F})$ and ${ }^{4} \mathrm{~T}_{1} \mathrm{~g} \rightarrow{ }^{4} \mathrm{~T}^{1} \mathrm{~g}(\mathrm{P})$ transitions, respectively. The magnetic moment value of the $\mathrm{Co}(\mathrm{II})\left(\mathrm{d}^{7}\right)$ complex is found to be 5.48 B.M. The spectrum resembles those reported for octahedral complexes [15], [18].

The diffused reflectance spectrum of $\mathrm{Ni}(\mathrm{II})$ complex showed bands at 14,880 and $16,447 \mathrm{~cm}^{-1}$ which can be assigned to ${ }^{3} \mathrm{~A}_{2 \mathrm{~g}} \rightarrow{ }^{3} \mathrm{~T}_{1 \mathrm{~g}}(\mathrm{~F})$ and ${ }^{3} \mathrm{~A}_{2 \mathrm{~g}} \rightarrow{ }^{3} \mathrm{~T}_{1 \mathrm{~g}}(\mathrm{P})$ transitions, respectively. The magnetic moment for the $\mathrm{Ni}(\mathrm{II})$ complex $\left(d^{8}\right)$ was found to be 3.43 B.M, which fall within the range of octahedral Ni(II) complexes [18][15][19]

The observed magnetic moments for $\mathrm{Cu}(\mathrm{II})$ complex was $1.80 \mathrm{~B} . \mathrm{M}$ and the band observed at $17241 \mathrm{~cm}^{-1}$ $\left({ }^{2} \mathrm{E}_{\mathrm{g}} \rightarrow{ }^{2} \mathrm{~T}_{2 \mathrm{~g}}\right)$ in the diffused reflectance spectrum suggested an octahedral geometry.[19]

$\mathrm{Zn}(\mathrm{II})$ and $\mathrm{Cd}(\mathrm{II})$ complexes are diamagnetic consistent with the $\left(\mathrm{d}^{10}\right)$ configuration [15].

\section{Geometry optimization}

Figure 3 shows the fully optimized geometries of the $\mathrm{H}_{2} \mathrm{~L}$ ligand plus its $\mathrm{Cu}(\mathrm{II})$ complex. Distorted octahedral geometry around the $\mathrm{Cu}(\mathrm{II})$ ion existed with the selected bond lengths and bond angles calculated for $\mathrm{Cu}(\mathrm{II})$ complex (Table 5). A small length elongation was found in bond lengths $C(13)-N(23), C(14)-N(24), C(28)$ $\mathrm{O}(31), \mathrm{C}(25)-\mathrm{N}(23)$ and $\mathrm{O}(38)-\mathrm{C} 39)$. In the $\mathrm{Cu}(\mathrm{II})$ complex, this is noted as the Schiff base ligand coordinated by two azomethine nitrogen, two oxygen, while two chloride ions took up other two positions. As previously stated, the bond angles in the $\mathrm{Cu}(\mathrm{II})$ coordination sphere were investigated and confirmed octahedral geometry [6]. 
Table 5

The different optimized and quantum chemical parameters of $\mathrm{H}_{2} \mathrm{~L}$ and its $\mathrm{Cu}(\mathrm{II})$ complex.

\begin{tabular}{|c|c|c|}
\hline Bond lengths $(\AA)$ & $\mathrm{H}_{2} \mathrm{~L}$ & {$\left[\mathrm{Cu}\left(\mathrm{H}_{2} \mathrm{~L}\right) \mathrm{Cl}_{2}\right] 4 \mathrm{H}_{2} \mathrm{O}$} \\
\hline$C(13)-N(23)$ & 1.29 & 1.64 \\
\hline$C(14)-N(24)$ & 1.30 & 1.64 \\
\hline$C(25)-N(23)$ & 1.46 & 2.09 \\
\hline$N(23)-C u(45)$ & - & 2.06 \\
\hline$N(24)-C(42)$ & 1.48 & 2.10 \\
\hline$N(24)-C u(45)$ & - & 1.96 \\
\hline $\mathrm{C}(28)-\mathrm{O}(31)$ & 1.44 & 1.80 \\
\hline$C(32)-O(31)$ & 1.44 & 1.49 \\
\hline $\mathrm{Cu}(45)-\mathrm{O}(31)$ & - & 1.92 \\
\hline$C(35)-O(38)$ & 1.44 & 1.55 \\
\hline O(38) -C39) & 1.44 & 1.84 \\
\hline $\mathrm{Cu}(45)-\mathrm{O}(38)$ & - & 1.76 \\
\hline $\mathrm{Cu}(45)-\mathrm{Cl}(46)$ & - & 2.16 \\
\hline $\mathrm{Cu}(45)-\mathrm{Cl}(47)$ & - & 2.16 \\
\hline \multicolumn{3}{|l|}{ Bond angles $\left({ }^{\circ}\right)$} \\
\hline $\mathrm{N}(23)-\mathrm{Cu}(45)-\mathrm{N}(24)$ & - & 120 \\
\hline $\mathrm{N}(23)-\mathrm{Cu}(45)-\mathrm{O}(31)$ & - & 81 \\
\hline $\mathrm{N}(24)-\mathrm{Cu}(45)-\mathrm{O}(38)$ & - & 85 \\
\hline $\mathrm{O}(31)-\mathrm{Cu}(45)-\mathrm{Cl}(46)$ & - & 111 \\
\hline $\mathrm{O}(31)-\mathrm{Cu}(45)-\mathrm{Cl}(47)$ & - & 118 \\
\hline $\mathrm{O}(38)-\mathrm{Cu}(45)-\mathrm{Cl}(46)$ & - & 119 \\
\hline $\mathrm{O}(38)-\mathrm{Cu}(45)-\mathrm{Cl}(47)$ & & 112 \\
\hline $\mathrm{Cl}(47)-\mathrm{Cu}(45)-\mathrm{Cl}(46)$ & & 115 \\
\hline \multicolumn{3}{|c|}{ The calculated quantum chemical parameters } \\
\hline E (a.u.) & 1032.969 & -1259.304 \\
\hline Dipole moment (Debye) & 1.3445 & 3.5586 \\
\hline $\mathrm{E}_{\text {HOMO }}(\mathrm{eV})$ & -5.99 & -6.41 \\
\hline
\end{tabular}




\begin{tabular}{|lll|}
\hline Bond lengths $(\AA)$ & $\mathrm{H}_{2} \mathrm{~L}$ & {$\left[\mathrm{Cu}\left(\mathrm{H}_{2} \mathrm{~L}\right) \mathrm{Cl}_{2}\right] 4 \mathrm{H}_{2} \mathrm{O}$} \\
\hline $\mathrm{E}_{\mathrm{LUMO}}(\mathrm{eV})$ & -0.96 & -1.66 \\
\hline$\Delta \mathrm{E}(\mathrm{eV})$ & 5.03 & 4.75 \\
\hline$\chi(\mathrm{eV})$ & -3.48 & -4.04 \\
\hline$\eta(\mathrm{eV})$ & 2.52 & 2.38 \\
$\sigma(\mathrm{eV})^{-1}$ & 0.40 & 0.42 \\
\hline $\mathrm{Pi}(\mathrm{eV})$ & 3.48 & 4.04 \\
\hline$S(\mathrm{eV})^{-1}$ & 0.20 & 0.21 \\
\hline$\omega(\mathrm{eV})$ & 2.40 & 3.43 \\
\hline$\Delta \mathrm{N}_{\max }$ & -1.38 & -1.70 \\
\hline
\end{tabular}

\section{Molecular electrostatic potential (MEP)}

To determine the electrical charge distribution around the molecular surface and therefore expect sites for these reactions, electrostatic potential $V(r)$ maps, were investigated. These maps have been determined on the same basis as for optimization. 3D plots of MEPs for the ligand and its $\mathrm{Cu}$ (II) complex have been drawn in the existing study. On the basis of the MEP, the electron-rich field that is red on the map can be ordered in the majority (a favorite position for electrophilic attack). The neutral electrostatic potential region points outside the green colored region. The $\mathrm{H}_{2} \mathrm{~L}$ is stable and has nearly uniform load density distribution. However, two oxygen and two nitrogen atoms are surrounded by a large negative charge surface, which could lead to electrophilic attacks on these sites (red) (Fig. 4) [6].

In conditions of electron density, the aromatic ring appears neutral. This means that the distribution of potential supports the complexation reaction that is further confirmed through the electrostatic potential distribution of $\mathrm{Cu}$ (II) complex where the metal center has a larger negative load (Fig. 4b). In addition to the increase of the electron negative capacity of $\mathrm{Cu}(\mathrm{II})$ oxygen and nitrogen as free $\mathrm{H}_{2} \mathrm{~L}$, the Mulliken electron negative is the favored location for electrical attacks with copper ion. The charge of $\mathrm{Cu}$ atom decreased from $(+2$ to +0.08$)$ due to coordination sphere process (Table 7) [6].

\section{Molecular parameters}

Following on from our work [6] before. Table 5 lists the free $\mathrm{H}_{2}$ L ligand with its $\mathrm{Cu}(\mathrm{II})$ complex. The $\mathrm{Cu}(\mathrm{II})$ complex displayed high dipole values compared to the free ligand. The main orbital elements participating in chemical stability were the highest occupied molecular orbital (HOMO) and the lowest occupied molecular orbital (LUMO). The HOMO is an electron donation capability, LUMO is an electron accepting device, it is an electron donation capability. It can assume from the achieved data that: 
The HOMO and LUMO energies were negative, and more negative than free $\mathrm{H}_{2} \mathrm{~L}$, confirming lonely complex stability. The $\mathrm{Cu}(\mathrm{II})$ component $\mathrm{E}_{\mathrm{HOMO}}$ and $\mathrm{E}_{\mathrm{LUMO}}$ values have been calculated and showed a lower $\mathrm{Cu}(\mathrm{II})-\mathrm{H}_{2} \mathrm{~L}$ bond strength than the free ligand. The total energy of $\mathrm{Cu}(\mathrm{II})$ is larger than the free ligand, and the consistency of the solid lonely complex is highly evident. The little energy divide can be linked to a high chemical reactivity, low kinetic stability, and the highly polarizing molecule mirror to active electronic charge transfer interaction. Azomethine nitrogens and etheric oxygens were usually located at the HOMO levels of the ligand phenol groups, which indicated the preferred places of nuclear attack against the central metal atom. $\mathrm{H}_{2} \mathrm{Landits} \mathrm{Cu}(\mathrm{II})$ complex contains different optimized and quantum chemical parameters (Table 5). [4, 6].

\section{UV-Vis spectra}

In addition to appropriate excited states, the photochemistry of transition metal compounds requires information regarding the characteristics of molecular orbits. Frontier orbitals play a major role in such systems as they control the electronic stimuli and the typeset of transitions. With the help of TD-DFT estimates, the charity of the ligands and metal orbitals are likely to be commented on molecular orbitals. All electronic transitions and orbitals are not practical to analysis; thus certain constraints are applied. It has been popularized in favor of theoretical research into the electronic molecules spectrum due to its high accuracy and low computational costs of TD-DFT. The present study was carried out in the TD-DFT/B3LYP/LANL2DZ theory level of 30 single tested states for the small laying excited status of $\mathrm{H}_{2} \mathrm{~L}$ with its $\mathrm{Cu}(\mathrm{II})$ complex on optimized ground status structures. Experimental and electronic theoretical spectrums existed. In Table 6, the experimental and theoretical electronic spectra were existing. The TD-DFT calculations have been estimated in the $\mathrm{N}, \mathrm{N}$-dimethylformamide solvent background and compared by the experimental data. The transitions aimed interfrontier orbitals for wavelengths matching to maximum oscillator strength of simulated results with contemporary experimental observations were presented in Figure $(5 a, b)$. For example, the electronic transitions for $\mathrm{H}_{2} \mathrm{~L}$ obtained at calculated $276 \mathrm{~nm}$ match to experimental peak at $262 \mathrm{~nm}$. This transition has been majorly contributed from HOMO to LUMO transitions which were primarily $\pi \rightarrow \pi^{*}$ in nature. The various transitions and their experimental matching part of the free ligand and its $\mathrm{Cu}(\mathrm{II})$ complex have been summarized in Table $6[4,6]$.

Table 6. Main calculated optical transition with composite ion in terms of molecular orbitals. 


\begin{tabular}{|llllll|}
\hline Compound & Transition & $\begin{array}{l}\text { Excitation energy } \\
(\mathbf{e v})\end{array}$ & $\begin{array}{l}\lambda_{\max } \text { Calc. } \\
(\mathrm{nm})\end{array}$ & $\begin{array}{l}\lambda_{\max } \text { exp. } \\
(\mathrm{nm})\end{array}$ & $\begin{array}{l}\text { Oscillating } \\
\text { strength }\end{array}$ \\
\hline $\mathrm{H}_{2} \mathrm{~L}$ & $\begin{array}{c}\mathrm{HOMO} \\
\mathrm{LUMO}\end{array}$ & 4.49 & 276 & 262 & 0.064 \\
\hline$\left[\mathrm{Cu}\left(\mathrm{H}_{2} \mathrm{~L}\right) \mathrm{Cl}_{2}\right] 4 \mathrm{H}_{2} \mathrm{O}$ & & & & & \\
& $\begin{array}{l}\mathrm{HOMO}-1 \\
\mathrm{LUMO}\end{array}$ & 4.39 & 282 & 263 & 0.013 \\
& & & & & \\
\hline
\end{tabular}

\section{Thermogravimetric analysis}

TGA was carried out for solid Schiff base ligand and its metal complexes under nitrogen flow. Thermal data of the complexes were shown in Table 8. The heating rate was suitably controlled at $30^{\circ} \mathrm{C} \mathrm{min}^{-1}$ and the weight losses were measured from the ambient temperature up to $1000^{\circ} \mathrm{C}$. 
Table 8

Thermoanalytical results (TG and DTG) of Schiff base ligand $\left(\mathrm{H}_{2} \mathrm{~L}\right)$ and its metal complexes.

\begin{tabular}{|c|c|c|}
\hline \multirow[t]{2}{*}{ Atom } & $\mathrm{H}_{2} \mathrm{~L}$ & {$\left[\mathrm{Cu}\left(\mathrm{H}_{2} \mathrm{~L}\right) \mathrm{Cl}_{2}\right] 4 \mathrm{H}_{2} \mathrm{O}$} \\
\hline & \multicolumn{2}{|c|}{ Mulliken charge } \\
\hline $1 \mathrm{C}$ & 0.161390 & 0.084079 \\
\hline $2 C$ & 0.017149 & -0.289215 \\
\hline $3 \mathrm{C}$ & 0.152033 & 0.096566 \\
\hline $4 \mathrm{C}$ & 0.117463 & 0.387069 \\
\hline $5 \mathrm{C}$ & 0.051311 & -0.231235 \\
\hline $6 \mathrm{C}$ & 0.106932 & 0.330040 \\
\hline 90 & -0.258556 & -0.148050 \\
\hline 110 & -0.250780 & -0.147352 \\
\hline $13 \mathrm{C}$ & 0.169619 & 0.139595 \\
\hline $14 \mathrm{C}$ & 0.151273 & 0.126762 \\
\hline $15 \mathrm{C}$ & -0.000299 & 0.033911 \\
\hline 19 C & 0.009909 & 0.038200 \\
\hline $23 \mathrm{~N}$ & -0.352717 & -0.228657 \\
\hline $24 N$ & -0.359838 & -0.245915 \\
\hline $25 \mathrm{C}$ & 0.135447 & 0.006493 \\
\hline $28 \mathrm{C}$ & 0.257876 & 0.253436 \\
\hline 310 & -0.504369 & -0.397787 \\
\hline $32 \mathrm{C}$ & 0.251665 & 0.213836 \\
\hline $35 \mathrm{C}$ & 0.250398 & 0.219458 \\
\hline 380 & -0.503025 & -0.443001 \\
\hline $39 \mathrm{C}$ & 0.260257 & 0.257745 \\
\hline $42 \mathrm{C}$ & 0.136862 & 0.020067 \\
\hline $45 \mathrm{Cu}$ & & 0.088369 \\
\hline $46 \mathrm{Cl}$ & & -0.079872 \\
\hline $47 \mathrm{Cl}$ & & -0.084543 \\
\hline
\end{tabular}


Table8. Thermoanalytical results (TG and DTG) of Schiff base ligand $\left(\mathrm{H}_{2} \mathrm{~L}\right)$ and its metal complexes. 


\begin{tabular}{|c|c|c|c|c|c|c|}
\hline Complex & $\begin{array}{l}\text { TG } \\
\text { range } \\
\left({ }^{\circ} \mathrm{C}\right)\end{array}$ & $\begin{array}{l}\mathrm{DTG}_{\max } \\
\left({ }^{\circ} \mathrm{C}\right)\end{array}$ & $\mathrm{n}^{*}$ & $\begin{array}{l}\text { Mass loss } \\
\text { Total mass } \\
\text { loss } \\
\text { Estim (Calcd) } \\
\%\end{array}$ & Assignment & Residues \\
\hline \multirow[t]{2}{*}{$\mathrm{H}_{2} \mathrm{~L}$} & $\begin{array}{l}30- \\
295\end{array}$ & 132,253 & 2 & $39.51(37.86)$ & -Loss of $\mathrm{C}_{6} \mathrm{H}_{12} \mathrm{O}_{2}$. & \multirow[t]{2}{*}{$\ldots \ldots \ldots \ldots}$. \\
\hline & $\begin{array}{l}295- \\
1000\end{array}$ & 380,400 & 2 & $\begin{array}{l}60.42(62.14) \\
99.93(100.00)\end{array}$ & $\begin{array}{l}\text {-Loss of } \mathrm{C}_{10} \\
\mathrm{H}_{10} \mathrm{~N}_{2} \mathrm{O}_{2}\end{array}$ & \\
\hline \multirow{4}{*}{$\begin{array}{l}{\left[\mathrm{Cr}\left(\mathrm{H}_{2} \mathrm{~L}\right)\right.} \\
\left.\left(\mathrm{H}_{2} \mathrm{O}\right) \mathrm{Cl}\right] \mathrm{Cl}_{2} \cdot 3 \mathrm{H}_{2} \mathrm{O}\end{array}$} & \multirow{2}{*}{$\begin{array}{l}30- \\
129\end{array}$} & 62 & 1 & $10.19(10.06)$ & -Loss of $3 \mathrm{H}_{2} \mathrm{O}$. & \multirow{4}{*}{$\begin{array}{l}1 /{ }_{2} \mathrm{Cr}_{2} \mathrm{O}_{3} \\
+4 \mathrm{C}\end{array}$} \\
\hline & & 182,396 & 2 & $29.46(28.78)$ & \multirow{2}{*}{$\begin{array}{l}\text {-Loss of } 1.5 \mathrm{Cl}_{2} \\
\mathrm{H}_{2} \mathrm{O} \text { and } \mathrm{C}_{2} \mathrm{H}_{6}\end{array}$} & \\
\hline & $\begin{array}{l}129- \\
402\end{array}$ & \multirow[t]{2}{*}{$410,430,609$} & \multirow[t]{2}{*}{3} & \multirow{2}{*}{$\begin{array}{l}42.40(42.47) \\
82.05(81.31)\end{array}$} & & \\
\hline & $\begin{array}{l}402- \\
1000\end{array}$ & & & & $\begin{array}{l}\text {-Loss of } \mathrm{C}_{12} \\
\mathrm{H}_{16} \mathrm{~N}_{2} \mathrm{O}_{2.5}\end{array}$ & \\
\hline \multirow{2}{*}{$\begin{array}{l}{\left[\mathrm{Mn}\left(\mathrm{H}_{2} \mathrm{~L}\right)\right.} \\
\left.\left(\mathrm{H}_{2} \mathrm{O}\right)_{2}\right] \mathrm{Cl}_{2} \cdot 2 \mathrm{H}_{2} \mathrm{O}\end{array}$} & $\begin{array}{l}30- \\
156\end{array}$ & 125 & 1 & $13.96(14.27)$ & -Loss of $4 \mathrm{H}_{2} \mathrm{O}$ & \multirow{2}{*}{$\begin{array}{l}\mathrm{MnO}+ \\
6 \mathrm{C}\end{array}$} \\
\hline & $\begin{array}{l}156- \\
1000\end{array}$ & 210,230 & 2 & $\begin{array}{l}56.66(57.30) \\
70.62(71.57)\end{array}$ & $\begin{array}{l}\text {-Loss of } \mathrm{Cl}_{2} \text { and } \\
\mathrm{C}_{10} \mathrm{H}_{22} \mathrm{~N}_{2} \mathrm{O}_{3}\end{array}$ & \\
\hline \multirow{5}{*}{$\begin{array}{l}{\left[\mathrm{Fe}\left(\mathrm{H}_{2} \mathrm{~L}\right) \mathrm{Cl}\right.} \\
\left.{ }_{2}\right] \mathrm{Cl}_{2} \mathrm{H}_{2} \mathrm{O}\end{array}$} & \multirow{2}{*}{$\begin{array}{l}30- \\
109\end{array}$} & 76 & 1 & $6.76(7.13)$ & - Loss of $2 \mathrm{H}_{2} \mathrm{O}$ & \multirow{5}{*}{$\begin{array}{l}1 / 2 \mathrm{Fe}_{2} \mathrm{O}_{3} \\
+3 \mathrm{C}\end{array}$} \\
\hline & & 153 & 1 & $7.94(7.03)$ & \multirow{3}{*}{$\begin{array}{l}\text {-Loss of } 0.5 \mathrm{Cl}_{2} \\
\text {-Loss of } \mathrm{Cl}_{2} \text { and } \\
\mathrm{C}_{2} \mathrm{H}_{6}\end{array}$} & \\
\hline & $\begin{array}{l}109- \\
178\end{array}$ & 194 & 1 & $20.39(20.00)$ & & \\
\hline & $\begin{array}{l}178- \\
316\end{array}$ & \multirow[t]{2}{*}{320,435} & \multirow[t]{2}{*}{2} & \multirow[t]{2}{*}{$\begin{array}{l}47.67(47.54) \\
82.76(81.70)\end{array}$} & & \\
\hline & $\begin{array}{l}316- \\
1000\end{array}$ & & & & $\begin{array}{l}\text {-Loss of } \mathrm{C}_{13} \\
\mathrm{H}_{16} \mathrm{~N}_{2} \mathrm{O}_{2.5}\end{array}$ & \\
\hline \multirow{2}{*}{$\begin{array}{l}{\left[\mathrm{Co}\left(\mathrm{H}_{2} \mathrm{~L}\right)\right.} \\
\left.\left(\mathrm{H}_{2} \mathrm{O}\right)_{2}\right] \mathrm{Cl}_{2} \cdot \mathrm{H}_{2} \mathrm{O}\end{array}$} & \multirow{2}{*}{$\begin{array}{l}30- \\
159 \\
159- \\
1000\end{array}$} & 127 & 1 & $11.61(11.01)$ & -Loss of $3 \mathrm{H}_{2} \mathrm{O}$ & \multirow[t]{2}{*}{$\mathrm{CoO}+2 \mathrm{C}$} \\
\hline & & 229,425 & 2 & $\begin{array}{l}67.78(68.72) \\
79.39(79.73)\end{array}$ & $\begin{array}{l}\text {-Loss of } \mathrm{Cl}_{2} \text { and } \\
\mathrm{C}_{14} \mathrm{H}_{22} \mathrm{~N}_{2} \mathrm{O}_{3} \text {. }\end{array}$ & \\
\hline$\left[\mathrm{Ni}\left(\mathrm{H}_{2} \mathrm{~L}\right)\left(\mathrm{H}_{2} \mathrm{O}\right)\right.$ & $30-$ & 66,135 & 2 & $21.39(21.15)$ & -Loss of $4 \mathrm{H}_{2} \mathrm{O}$ & $\mathrm{NiO}+\mathrm{C}$ \\
\hline $\mathrm{Cl}] \mathrm{Cl} .3 \mathrm{H}_{2} \mathrm{O}$ & $\begin{array}{l}165 \\
105- \\
1000\end{array}$ & $226,506,820$ & 3 & $\begin{array}{l}55.94(54.68) \\
77.33(75.83)\end{array}$ & $\begin{array}{l}0.5 \mathrm{Cl}_{2} \\
\text {-Loss of } 0.5 \mathrm{Cl}_{2} \\
\text { and } \mathrm{C}_{15} \mathrm{H}_{22} \mathrm{~N}_{2} \mathrm{O}_{3} \text {. }\end{array}$ & \\
\hline
\end{tabular}

* $\mathrm{n}=$ number of decomposition steps. 


\begin{tabular}{|c|c|c|c|c|c|c|}
\hline Complex & $\begin{array}{l}\text { TG } \\
\text { range } \\
\left({ }^{\circ} \mathrm{C}\right)\end{array}$ & $\begin{array}{l}\mathrm{DTG}_{\max } \\
\left({ }^{\circ} \mathrm{C}\right)\end{array}$ & $\mathrm{n}^{*}$ & $\begin{array}{l}\text { Mass loss } \\
\text { Total mass } \\
\text { loss } \\
\text { Estim (Calcd) } \\
\%\end{array}$ & Assignment & Residues \\
\hline \multirow[t]{4}{*}[\mathrm{Cu}(\mathrm{H}_{2}\mathrm{L})\mathrm{Cl}_{2}]{$4 \mathrm{H}_{2} \mathrm{O}$} & \multirow{2}{*}{$\begin{array}{l}30- \\
86\end{array}$} & 74 & 1 & $6.70(7.02)$ & \multirow{4}{*}{$\begin{array}{l}\text {-Loss of } 2 \mathrm{H}_{2} \mathrm{O} \text {. } \\
\text {-Loss of } 2 \mathrm{H}_{2} \mathrm{O} \text { and } \\
\mathrm{Cl}_{2} \\
\text {-Loss of } \\
\mathrm{C}_{12} \mathrm{H}_{22} \mathrm{~N}_{2} \mathrm{O}_{3} \text {. }\end{array}$} & \multirow[t]{4}{*}{$\mathrm{CuO}+4 \mathrm{C}$} \\
\hline & & 150 & 1 & $21.45(20.86)$ & & \\
\hline & $\begin{array}{l}86- \\
194\end{array}$ & $199,269,805$ & 3 & $\begin{array}{l}46.66(47.18) \\
74.81(75.06)\end{array}$ & & \\
\hline & $\begin{array}{l}194- \\
1000\end{array}$ & & & & & \\
\hline \multirow[t]{2}{*}[\mathrm{Zn}(\mathrm{H}_{2}\mathrm{L})\mathrm{Cl}_{2}]{$2 \mathrm{H}_{2} \mathrm{O}$} & $\begin{array}{l}30- \\
258\end{array}$ & $95,140,212,239$ & 4 & $21.36(22.37)$ & -Loss of $\mathrm{Cl}_{2}, 2 \mathrm{H}_{2} \mathrm{O}$ & \multirow[t]{2}{*}{$\mathrm{ZnO}+\mathrm{C}$} \\
\hline & $\begin{array}{l}258- \\
1000\end{array}$ & 319,498 & 2 & $\begin{array}{l}58.82(58.11) \\
80.18(80.48)\end{array}$ & $\begin{array}{l}\text {-Loss of } \\
\mathrm{C}_{15} \mathrm{H}_{22} \mathrm{~N}_{2} \mathrm{O}_{3}\end{array}$ & \\
\hline \multirow[t]{4}{*}[\mathrm{Cd}(\mathrm{H}_{2}\mathrm{L})\mathrm{Cl}_{2}]{$\mathrm{H}_{2} \mathrm{O}$} & \multirow{2}{*}{$\begin{array}{l}30- \\
149\end{array}$} & 67 & 1 & $3.60(3.54)$ & -Loss of $\mathrm{H}_{2} \mathrm{O}$. & \multirow[t]{4}{*}{$\mathrm{CdO}$} \\
\hline & & 202 & 1 & 7.60 (6.99) & -Loss of $0.5 \mathrm{Cl}_{2}$ & \\
\hline & 247 & \multirow[t]{2}{*}{$300,571,760,988$} & \multirow[t]{2}{*}{4} & \multirow[t]{2}{*}{$\begin{array}{l}64.11(64.10) \\
74.31(74.63)\end{array}$} & \multirow{2}{*}{$\begin{array}{l}\text { - Loss of } 0.5 \mathrm{Cl}_{2} \\
\text { and } \mathrm{C}_{16} \mathrm{H}_{22} \mathrm{~N}_{2} \mathrm{O}_{3} \text {. }\end{array}$} & \\
\hline & $\begin{array}{l}247- \\
1000\end{array}$ & & & & & \\
\hline
\end{tabular}

The TGA and DTG curve of Schiff base ligand indicated that it was decomposed into four main steps. Where, the 1 st and 2nd steps involved the removal of $\mathrm{C}_{6} \mathrm{H}_{12} \mathrm{O}_{2}$ molecule (calculated $37.86 \%$, experimental $39.51 \%$ ) within the temperature range of $30-295^{\circ} \mathrm{C}$. The remaining part of the ligand $\left(\mathrm{C}_{10} \mathrm{H}_{10} \mathrm{~N}_{2} \mathrm{O}_{2}\right.$ molecule) was decomposed in the temperature range of $295-1000{ }^{\circ} \mathrm{C}$ (calculated $62.14 \%$, experimental $60.42 \%$ ) for the $3 \mathrm{rd}$ and 4 th steps and indicated complete decomposition of the ligand.

The TGA and DTG curve of $\left[\mathrm{Cr}\left(\mathrm{H}_{2} \mathrm{~L}\right)\left(\mathrm{H}_{2} \mathrm{O}\right) \mathrm{Cl}\right] \mathrm{Cl}_{2} \cdot 3 \mathrm{H}_{2} \mathrm{O}$ complex indicated that the complex was decomposed into six main steps. The major fragmentation occurred at $30-129^{\circ} \mathrm{C}$ temperature range and involved the decomposition of three $\mathrm{H}_{2} \mathrm{O}$ molecules (calculated $10.06 \%$, experimental $10.19 \%$ ). The other molecules of the complex $\left(1.5 \mathrm{Cl}_{2}, \mathrm{H}_{2} \mathrm{O}\right.$ and $\mathrm{C}_{2} \mathrm{H}_{6}$ molecules) were decomposed between temperature range of $129-402{ }^{\circ} \mathrm{C}$ (calculated $28.78 \%$, experimental $29.46 \%$ ) within the 2 nd and 3 rd steps of decomposition. The complex is completely decomposed in the temperature range of $402-1000^{\circ} \mathrm{C}$ (calculated $42.47 \%$, experimental $42.40 \%$ ) at last three steps and $1 /{ }_{2} \mathrm{Cr}_{2} \mathrm{O}_{3}$ contaminated by carbon atoms was left as the residue [20].

The TGA and DTG curve of $\left[\mathrm{Mn}\left(\mathrm{H}_{2} \mathrm{~L}\right)\left(\mathrm{H}_{2} \mathrm{O}\right)_{2}\right] \mathrm{Cl}_{2} \cdot 2 \mathrm{H}_{2} \mathrm{O}$ complex indicated that the complex was decomposed into three main steps. The major fragmentation occurred within the $30-156^{\circ} \mathrm{C}$ temperature range and involved the decomposition of four water molecules as a part of complex (calculated $14.27 \%$, experimental 
13.96\%). The other part of the complex $\left(\mathrm{Cl}_{2}\right.$ and $\mathrm{C}_{10} \mathrm{H}_{22} \mathrm{~N}_{2} \mathrm{O}_{3}$ molecules) was decomposed between temperature range $156-1000{ }^{\circ} \mathrm{C}$ (calculated $57.30 \%$, experimental $56.66 \%$ ) at 2nd and 3rd steps of decomposition where complete decomposition and $\mathrm{MnO}$ contaminated by carbon atoms was left as a residue.

The TGA and DTG curve of $\left[\mathrm{Fe}\left(\mathrm{H}_{2} \mathrm{~L}\right) \mathrm{Cl}_{2}\right] \mathrm{Cl} .2 \mathrm{H}_{2} \mathrm{O}$ complex indicated that the complex was decomposed into 5 main steps. The major fragmentation occur at $30-109^{\circ} \mathrm{C}$ temperature range involves the decomposition of the part of complex $2 \mathrm{H}_{2} \mathrm{O}$ (calculated $7.13 \%$, experimental $6.76 \%$ weight). The other part of complex $-0.5 \mathrm{Cl}_{2}-$ was decomposed between temperature range $109-178{ }^{\circ} \mathrm{C}$ (calculated $7.03 \%$, experimental $7.94 \%$ weight) at 2nd Step of decomposition. The other part of complex $-\mathrm{Cl}_{2}$ and $\mathrm{C}_{2} \mathrm{H}_{6}$ - was decomposed between temperature range $178-316^{\circ} \mathrm{C}$ (calculated $20.00 \%$, experimental $20.39 \%$ weight) at 3rd Step of decomposition The complex is completely decomposed between temperature range $316-1000{ }^{\circ} \mathrm{C}$ (calculated $47.54 \%$, experimental $47.67 \%$ weight)at last two Steps and removed as $1 / 2 \mathrm{Fe}_{2} \mathrm{O}_{3}$ contaminated by carbon atoms as a residue was left.[20]

The TGA and DTG curve of $\left[\mathrm{Co}\left(\mathrm{H}_{2} \mathrm{~L}\right)\left(\mathrm{H}_{2} \mathrm{O}\right)_{2}\right] \mathrm{Cl}_{2} \cdot \mathrm{H}_{2} \mathrm{O}$ complex indicated that the complex was decomposed into 3 main steps. The major fragmentation occur at 30-159 ${ }^{\circ} \mathrm{C}$ temperature range involves the decomposition of the part of complex $3 \mathrm{H}_{2} \mathrm{O}$ (calculated $11.01 \%$, experimental $11.61 \%$ weight). The other part of complex $-\mathrm{Cl}_{2}$ and $\mathrm{C}_{14} \mathrm{H}_{22} \mathrm{~N}_{2} \mathrm{O}_{3}$ - was decomposed between temperature range $159-1000{ }^{\circ} \mathrm{C}$ (calculated $68.72 \%$, experimental $67.78 \%$ weight) at 2 nd and 3rd Steps of completely decomposition and removed as CoO contaminated by carbon atoms as a residue was left.

The TGA and DTG curve of $\left[\mathrm{Ni}\left(\mathrm{H}_{2} \mathrm{~L}\right)\left(\mathrm{H}_{2} \mathrm{O}\right) \mathrm{Cl}\right] \mathrm{Cl} .3 \mathrm{H}_{2} \mathrm{O}$ complex indicated that the complex was decomposed into 5 main steps. The major fragmentation occur at $30-165^{\circ} \mathrm{C}$ temperature range involves the decomposition of the part of complex $4 \mathrm{H}_{2} \mathrm{O}, 0.5 \mathrm{Cl}_{2}$ (calculated $21.15 \%$, experimental $21.39 \%$ weight). The other part of complex $0.5 \mathrm{Cl}_{2}$ and $\mathrm{C}_{15} \mathrm{H}_{22} \mathrm{~N}_{2} \mathrm{O}_{3}$.- was decomposed between temperature range $165-1000{ }^{\circ} \mathrm{C}$ (calculated $54.68 \%$, experimental $55.94 \%$ weight) at last three Steps of completely decomposition and removed as $\mathrm{NiO}$ contaminated by carbon atoms as a residue was left.

The TGA and DTG curve of $\left[\mathrm{Cu}\left(\mathrm{H}_{2} \mathrm{~L}\right) \mathrm{Cl}_{2}\right] 4 \mathrm{H}_{2} \mathrm{O}$ complex indicated that the complex was decomposed into 5 main steps. The major fragmentation occur at $30-86^{\circ} \mathrm{C}$ temperature range involves the decomposition of the part of complex $2 \mathrm{H}_{2} \mathrm{O}$ (calculated $7.02 \%$, experimental $6.70 \%$ weight). The other part of complex $-2 \mathrm{H}_{2} \mathrm{O}$ and $\mathrm{Cl}_{2}$ - was decomposed between temperature range $86-194^{\circ} \mathrm{C}$ (calculated $(20.86 \%$, experimental $21.45 \%$ weight) at 2nd Step of decomposition. The complex is completely decomposed between temperature range 194- $1000{ }^{\circ} \mathrm{C}$ (calculated $47.18 \%$, experimental $46.66 \%$ weight)at last three Steps and removed as CuO contaminated by carbon atoms as a residue was left.[20]

The TGA and DTG curve of $\left[\mathrm{Zn}\left(\mathrm{H}_{2} \mathrm{~L}\right) \mathrm{Cl}_{2}\right] 2 \mathrm{H}_{2} \mathrm{O}$ complex indicated that the complex was decomposed into 6 main steps. The major fragmentation occur at $30-258^{\circ} \mathrm{C}$ temperature range involves the decomposition of the part of complex $2 \mathrm{H}_{2} \mathrm{O}, \mathrm{Cl}_{2}$ (calculated 22.37\%, experimental $21.36 \%$ weight). The other part of complex $\mathrm{C}_{15} \mathrm{H}_{22} \mathrm{~N}_{2} \mathrm{O}_{3}$.- was decomposed between temperature range $258-1000{ }^{\circ} \mathrm{C}$ (calculated $58.11 \%$, experimental 
$58.82 \%$ weight) at last two Steps of completely decomposition and removed as $\mathrm{ZnO}$ contaminated by carbon atoms as a residue was left.

The TGA and DTG curve of $\left[\mathrm{Cd}\left(\mathrm{H}_{2} \mathrm{~L}\right) \mathrm{Cl}_{2}\right] \mathrm{H}_{2} \mathrm{O}$ complex indicated that the complex was decomposed into 6 main steps. The major fragmentation occur at $30-149{ }^{\circ} \mathrm{C}$ temperature range involves the decomposition of the part of complex $\mathrm{H}_{2} \mathrm{O}$ (calculated $3.54 \%$, experimental $3.60 \%$ weight). The other part of complex $-0.5 \mathrm{Cl}_{2}$.was decomposed between temperature range $149-247^{\circ} \mathrm{C}$ (calculated $6.99 \%$, experimental $7.60 \%$ weight) at 2nd Step of decomposition. The complex is completely decomposed between temperature range 247-1000 ${ }^{\circ} \mathrm{C}$ (calculated $64.10 \%$, experimental $64.11 \%$ weight)at last four Steps and removed as CdO as a residue was left.[20]

\section{X-ray powder diffraction}

XRD pattern of Schiff base ligand $\left(\mathrm{H}_{2} \mathrm{~L}\right)$ and the Co(II) complex are shown in Fig. 6. The XRD pattern of the $\mathrm{Co}$ (II) complex showed well defined crystalline peaks indicating that the sample was crystalline in phase. The metal complexes showed sharp crystalline XRD patterns, which differ considerably from that of the ligand. The grain size of the metal-Schiff base complexes, dXRD was calculated using Scherre's formula by measuring the full width at half maximum of the XRD peaks.

dXRD $=0.9 \lambda / \beta(\operatorname{Cos} \theta)$, where ' $\lambda$ ' is the wavelength, ' $\beta$ ' is the full width at half maximum and ' $\theta$ ' is the peak angle. The ligand and complex have the average crystallite size of 26 and $332 \mathrm{~nm}$ suggesting that Schiff base ligand $\left(\mathrm{H}_{2} \mathrm{~L}\right)$ and the complex are nanocrystalline, respectively [21, 22].

Powder XRD pattern of Schiff base ligand $\left(\mathrm{H}_{2} \mathrm{~L}\right)$ and $\mathrm{Co}(\mathrm{II})$ complex recorded in the range $(2 \Theta=0-80)$ were shown in Fig. 6a-b. XRD patterns showed the sharp crystalline peaks indicating their crystalline phase. The average crystallite size (dXRD) of them was calculated using Scherer's formula. The Schiff base ligand $\left(\mathrm{H}_{2} \mathrm{~L}\right)$ and Co(II) complex have crystallite size of $(27,15,37,33$ and 15) nm and $(1287,12,13$ and 16) nm, respectively $[23,24]$.

X-ray diffraction study of ligand showed a clear crystalline peaks with maxima at $2 \theta=15,10,22,24$ and $26^{\circ}$ and $d=5.68,9.13,4.10,3.70$ and $3.46 \AA$, respectively(Fig. 6a) [25].

Unlike Schiff base, the Co(II) complex had sharp peaks at $31^{\circ}$ and $d=2.90 \AA$ that might be assigned to coordination moiety [26]. X-ray diffraction study of Co(II) complex showed a clear crystalline peaks with maxima at $2 \theta=9,14,16$ and $31^{\circ}$ and $d=9.62,6.41,5.35$ and $2.9 \AA$, respectively (Fig. $6 b$ ). Powder XRD of all the other compounds exhibited their crystalline nature $[25,21,27]$

The obtained Co(II) complex shows sharp crystalline XRD patterns, which differ considerably from that of the ligand. The appearance of crystallinity in Co(II) Schiff base complex is due to the inherent crystalline nature of the metallic compound. [28]

\section{Structural interpretation}


The structures of the metal complexes of the tetradentate Schiff base ligand $\left(\mathrm{H}_{2} \mathrm{~L}\right)$ were characterized through elemental analyses, molar conductivity, IR, ${ }^{1} \mathrm{HNMR}$, UV-Vis, mass and thermal analyses after that the suggested structures of transition metal complexes were given in Fig. 7.

\section{Antimicrobial Studies}

The mean inhibitory activities of the ligand and its complexes against the tested microbes are shown in Table 9. Broad-spectrum antibacterial activities against pathogenic microbes have been reported for Schiff base ligand (Fig. 8). Coordination between biologically active Schiff base and metal ions are important components in the design of new metal-based therapeutic agents. The synthesized compounds exhibited significant activities against the screened microbes with variable grades of inhibitory properties. The metal(II) complexes were generally more active than the ligands and in some cases had comparable activity to those of the positive control drugs. The Co(II) complex had inhibitory zones of 21-22 mm against all the tested microbes with the exception of Aspergillus flavus. Additionally, Cd(II) complex showed inhibitory effects greater than that of the ligand and other complexes with inhibitory zones of $27 \mathrm{~mm}$ against only Aspergillus flavus. The increased sensitivity of the complexes might be attributed to hyper conjugation of the coordinated aromatic system and enhanced liposolubility which leads to a decrease in the polarity of metal ions and raises delocalization of $\pi$-electrons over the complex ring. Permeation of the metal(II) complexes through the lipid layers of the microbial membrane was favored by the latter, thus improving antimicrobial activity. Furthermore, chelation also deactivated various cellular enzymes, essential for metabolic pathways in the microorganisms. The Cd(II), Co(II) and Zn(II) complexes displayed the best antibacterial activity of all other synthesized compounds. The compound could be an antibiotic drug research interest in the near future.[5]

Table9. Biological activity of Schiff base ligand $\left(\mathrm{H}_{2} \mathrm{~L}\right)$ and its metal complexes. 


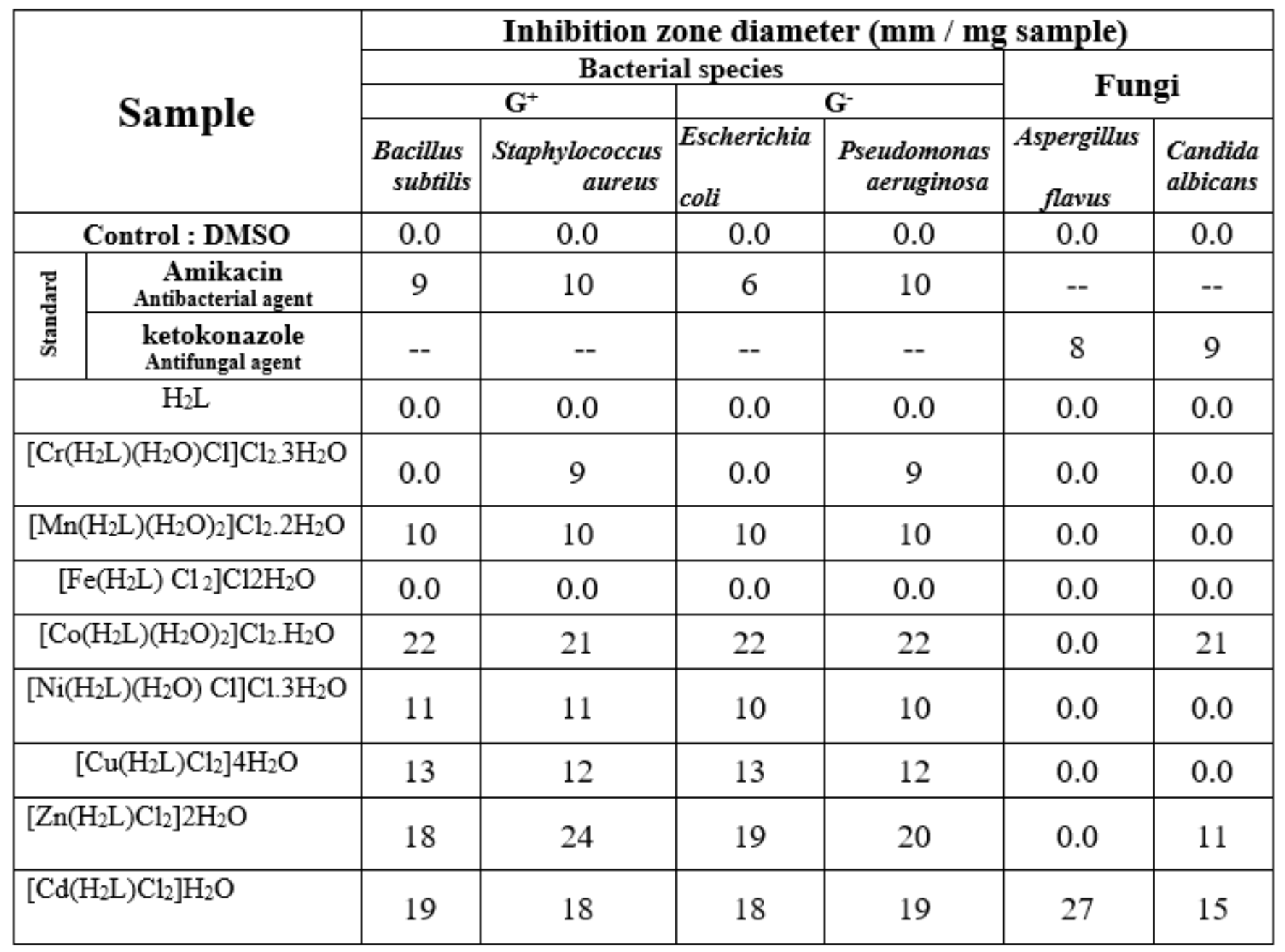

The activities of the prepared Schiff base ligand and its metal complexes were confirmed via calculating the activity index according to the following relation and that showed in Fig. 9.[29-30] Activity index (A) = (Inhibition zone of compound $(\mathrm{mm}) /$ Inhibition zone of standard drug $(\mathrm{mm})) \times 100$

\section{Molecular docking studies with DNA}

To further prudence into the interaction of Schiff base ligand and its metal complexes with DNA, molecular docking studies were conducted using DNA duplex of sequence (PDB ID: 6NE0) to portend the selected binding sites together with the chosen orientation of the molecule. The minimum energy conformation (Fig. 10) of $\mathrm{Co}(\mathrm{II})$ complex with DNA shows that it is located inside the minor groove slightly deeper inside the $\mathrm{G}-U$ rich region. The complex was comfortably fitted in a manner to effectively formed hydrogen bonding with the DNA phosphate back bone and the closer proximity of oxygen moiety of ligand allows suitable stacking interactions (partial intercalation) amongst DNA base pairs. The minimum energy docked pose of $\mathrm{Co}$ (II) complex also reveals the more negative binding energy which confirms its stronger binding affinity towards the DNA molecule which is in corroboration with the findings obtained from in vitro DNA binding experiments for Pseudomonas aeruginosa. Figure 10 and Table 10 showed the molecular docked model of Schiff base ligand and its metal complexes. They showed the electrostatic and partial intercalation between them and base pairs of PDB code 6NEO (structure of double-stranded target DNA engaged Csy complex from Pseudomonas aeruginosa (PA-14)) [31] 
Table 10

Energy values obtained in docking calculations of $\mathrm{H}_{2} \mathrm{~L}$ and its metal complexes with to PDB code 6NEO Structure of double-stranded target DNA engaged Csy complex from Pseudomonas aeruginosa (PA-14)

\begin{tabular}{|c|c|c|c|c|c|}
\hline COMPOUND & moiety & Receptor site & Interaction & $\begin{array}{l}\text { Distance } \\
\left(A^{\circ}\right)\end{array}$ & $\mathrm{E}(\mathrm{kcal} / \mathrm{mol})$ \\
\hline \multirow[t]{3}{*}{ Ligand $\mathrm{H}_{2} \mathrm{~L}$} & 038 & OP2 U 21 & H-donor & 3.18 & -2.7 \\
\hline & C11 26 & 6-ring G 19 & H-pi & 3.92 & -0.8 \\
\hline & C2 33 & 5-ring G 19 & H-pi & 4.28 & -0.6 \\
\hline \multirow{2}{*}[\mathrm{Cr}(\mathrm{H}_{2}\mathrm{L})(\mathrm{H}_{2}\mathrm{O})\mathrm{Cl}]{$\mathrm{Cl}_{2} \cdot 3 \mathrm{H}_{2} \mathrm{O}$} & 038 & OP1 C 20 & H-donor & 2.91 & -4.8 \\
\hline & C11 26 & 6-ring G 19 & H-pi & 4.34 & -0.6 \\
\hline$\left[\mathrm{Mn}\left(\mathrm{H}_{2} \mathrm{~L}\right)\left(\mathrm{H}_{2} \mathrm{O}\right)_{2}\right] \mathrm{Cl}_{2} \cdot 2 \mathrm{H}_{2} \mathrm{O}$ & 043 & OP2 U 21 & H-donor & 2.91 & -5.0 \\
\hline \multirow{2}{*}[\mathrm{Co}(\mathrm{H}_{2}\mathrm{L})(\mathrm{H}_{2}\mathrm{O})_{2}]{$\mathrm{Cl}_{2} \cdot \mathrm{H}_{2} \mathrm{O}$} & 043 & OP1 U 22 & H-donor & 2.89 & -6.2 \\
\hline & 047 & OP1 G 23 & H-donor & 2.79 & -7.6 \\
\hline \multirow[t]{5}{*}[\mathrm{Fe}(\mathrm{H}_{2}\mathrm{L})\mathrm{Cl}_{2}]{$\mathrm{Cl}_{2} \mathrm{H}_{2} \mathrm{O}$} & C11 4 & O2' G 19 & H-donor & 3.58 & -0.7 \\
\hline & C112 10 & O2' G 19 & H-donor & 3.65 & -0.5 \\
\hline & CL 46 & C5' C 20 & H-acceptor & 4.00 & -1.8 \\
\hline & CL 46 & C3' C 20 & H-acceptor & 3.83 & -2.9 \\
\hline & CL 47 & C3' C 20 & H-acceptor & 3.63 & -3.7 \\
\hline \multirow[t]{2}{*}[\mathrm{Ni}(\mathrm{H}_{2}\mathrm{L})(\mathrm{H}_{2}\mathrm{O})\mathrm{Cl}]{$\mathrm{Cl} .3 \mathrm{H}_{2} \mathrm{O}$} & 043 & OP2 U 21 & H-donor & 2.76 & -3.8 \\
\hline & C113 29 & 5-ring DG 21 & H-pi & 4.59 & -1.2 \\
\hline \multirow[t]{3}{*}[\mathrm{Cu}(\mathrm{H}_{2}\mathrm{L})\mathrm{Cl}_{2}]{$4 \mathrm{H}_{2} \mathrm{O}$} & 038 & OP1 G 23 & H-donor & 2.90 & -5.3 \\
\hline & 043 & OP1 U 22 & H-donor & 3.01 & -2.1 \\
\hline & CL 46 & N4 C 20 & H-acceptor & 3.37 & -4.8 \\
\hline$\left[\mathrm{Zn}\left(\mathrm{H}_{2} \mathrm{~L}\right) \mathrm{Cl}_{2}\right] 2 \mathrm{H}_{2} \mathrm{O}$ & 043 & OP1 C 20 & H-donor & 2.95 & -5.6 \\
\hline$\left[\mathrm{Cd}\left(\mathrm{H}_{2} \mathrm{~L}\right) \mathrm{Cl}_{2}\right] \mathrm{H}_{2} \mathrm{O}$ & 038 & OP1 U 22 & H-donor & 3.08 & -4.3 \\
\hline
\end{tabular}

On other hand the interaction of Schiff base ligand and its metal complexes with PDB code 6IY0 Crystal structure of conserved hypothetical protein SAV0927 from Staphylococcus aureus subsp. aureus Mu50, The minimum energy docked pose of $\mathrm{Zn}(\mathrm{II})$ complex also reveals the more negative binding energy which confirms its stronger binding affinity towards 6IY0. Figure 11 and Table 11 showed the molecular docked model of Schiff base ligand and its metal complexes. They showed the electrostatic and partial intercalation 
between them and base pairs of PDB code 6IYO. By comparing the experimental with the theoretical docking calculation, we found the results to be near to each other. 
Table 11

Energy values obtained in docking calculations of $\mathrm{H}_{2} \mathrm{~L}$ and its metal complexes with to PDB code 6 iyo

\begin{tabular}{|c|c|c|c|c|c|}
\hline COMPOUND & moiety & Receptor site & Interaction & $\begin{array}{l}\text { Distance } \\
\left(A^{\circ}\right)\end{array}$ & $\mathrm{E}(\mathrm{kcal} / \mathrm{mol})$ \\
\hline Ligand $\mathrm{H}_{2} \mathrm{~L}$ & C113 7 & O VAL 86 & H-donor & 3.15 & -0.8 \\
\hline$\left[\mathrm{Cr}\left(\mathrm{H}_{2} \mathrm{~L}\right)\left(\mathrm{H}_{2} \mathrm{O}\right) \mathrm{Cl}\right] \mathrm{Cl}_{2} \cdot 3 \mathrm{H}_{2} \mathrm{O}$ & 043 & O ASN 84 & H-donor & 3.16 & -2.7 \\
\hline \multirow{2}{*}[\mathrm{Mn}(\mathrm{H}_{2}\mathrm{L})(\mathrm{H}_{2}\mathrm{O})_{2}]{$\mathrm{Cl}_{2} \cdot 2 \mathrm{H}_{2} \mathrm{O}$} & 046 & OE2 GLU 75 & H-donor & 2.76 & -7.1 \\
\hline & 047 & OE1 GLN 47 & H-donor & 2.98 & -5.7 \\
\hline \multirow[t]{2}{*}[\mathrm{Co}(\mathrm{H}_{2}\mathrm{L})(\mathrm{H}_{2}\mathrm{O})_{2}]{$\mathrm{Cl}_{2} \cdot \mathrm{H}_{2} \mathrm{O}$} & C114 & OD1 ASP 77 & H-donor & 3.13 & -0.9 \\
\hline & 046 & OE1 GLU 61 & H-donor & 2.65 & -8.9 \\
\hline \multirow{5}{*}[\mathrm{Fe}(\mathrm{H}_{2}\mathrm{L})\mathrm{Cl}_{2}]{$\mathrm{Cl} 2 \mathrm{H}_{2} \mathrm{O}$} & C113 7 & OG1 THR 41 & H-donor & 2.90 & -1.8 \\
\hline & CL 46 & CA LEU 83 & H-acceptor & 3.42 & -2.4 \\
\hline & CL 46 & CB VAL 86 & H-acceptor & 3.50 & -1.7 \\
\hline & CL 47 & CA LEU 83 & H-acceptor & 3.42 & -2.4 \\
\hline & CL 47 & CB VAL 86 & H-acceptor & 3.50 & -1.7 \\
\hline \multirow[t]{4}{*}[\mathrm{Ni}(\mathrm{H}_{2}\mathrm{L})(\mathrm{H}_{2}\mathrm{O})\mathrm{Cl}]{$\mathrm{Cl} .3 \mathrm{H}_{2} \mathrm{O}$} & C11 4 & OE1 GLN 47 & H-donor & 3.36 & -0.7 \\
\hline & C2 17 & OD1 ASN 45 & H-donor & 3.22 & -0.8 \\
\hline & 047 & OG1 THR 48 & H-donor & 2.65 & -4.3 \\
\hline & 047 & O GLY 70 & H-donor & 2.73 & -7.4 \\
\hline \multirow[t]{3}{*}[\mathrm{Cu}(\mathrm{H}_{2}\mathrm{L})\mathrm{Cl}_{2}]{$4 \mathrm{H}_{2} \mathrm{O}$} & 043 & OE2 GLU 75 & H-donor & 2.92 & -7.5 \\
\hline & CL 46 & ND2 ASN 72 & H-acceptor & 3.69 & -4.1 \\
\hline & CL 47 & ND2 ASN 72 & H-acceptor & 3.95 & -0.6 \\
\hline \multirow[t]{2}{*}[\mathrm{Zn}(\mathrm{H}_{2}\mathrm{L})\mathrm{Cl}_{2}]{$2 \mathrm{H}_{2} \mathrm{O}$} & CL 46 & NZ LYS 40 & H-acceptor & 3.17 & -1.7 \\
\hline & CL 47 & NZ LYS 40 & H-acceptor & 3.30 & -14.4 \\
\hline \multirow[t]{3}{*}[\mathrm{Cd}(\mathrm{H}_{2}\mathrm{L})\mathrm{Cl}_{2}]{$\mathrm{H}_{2} \mathrm{O}$} & 038 & OD1 ASP 58 & H-donor & 3.31 & -1.5 \\
\hline & CL 46 & NZ LYS 40 & H-acceptor & 3.42 & -2.1 \\
\hline & CL 47 & NZ LYS 40 & H-acceptor & 3.60 & -9.7 \\
\hline
\end{tabular}

\section{Conclusion}


The new Schiff base ligand is synthesized and characterized. The results showed the coordination of $\mathrm{H}_{2} \mathrm{~L}$ format with metal ions through the $2 \mathrm{~N}$ and $2 \mathrm{O}$ as a donor atom. The results of the electron spectra and the magnetic susceptibility of all complexes show that these complexes are of octahedral geometry and the participation of the Schiff base in chelation in a tetradentate fashion. The ligand to metal stoichiometry and the nature of bonding was ascertained on the basis elemental analyses, position of molecular ion peaks in the mass spectra and conductivity data. The geometry of the compounds was investigated using DFT calculations and their thermodynamic and electronic parameters. Physicochemical results showed that the compounds were non-hygroscopic, solid and stable at room temperature. Biological findings indicate that complexation may increase or decrease the antimicrobial activity of some complexes. This could be endorsed to an increase of complexes lipophilicity in comparison to the parent ligand. the MOE were typically concise with the experimental data.

\section{References}

[1]S. A. Moustafa, M. M. Ali, and A. A. El-rashedy, "Synthesis, anticancer activity and molecular docking study of Schiff base complexes containing thiazole moiety," Beni-Suef Univ. J. Basic Appl. Sci., vol. 5, no. 1, pp. 8596, 2016.

[2]H. I. Alarabi, S. S. Mohamed, W. A. Suayed, I. A. Al-sadawe, and M. Salah, "Antimicrobial Evaluation of Novel Metals Complexes of nlsonicotinamido-2-hydroxy-5-methoxybenzalaldimine," vol. 2, no. 2, pp. 39-55, 2018.

[3]B. K. Singh, "Spectroscopic, electrochemical and biological studies of the metal complexes of the Schiff base derived from pyrrole-2-carbaldehyde and ethylenediamine," Arab. J. Chem., 2012.

[4]F. Chioma and C. D. Don-lawson, "Synthesis, spectral , magnetic and in-vitro biological studies of organic ligands and their corresponding heteroleptic divalent d-metal complexes," vol. 5, no. 3, pp. 118-129, 2018.

[5]F. Chioma et al., "properties , molecular docking and DFT studies of and Zn ( II ) complexes Ni ( II )," pp. 184-200, 2018.

[6]A. W. Bauer, W. M. Kirby, J. C. Sherris, and M. Turck, "Antibiotic susceptibility testing by a standardized single disk method.," Am. J. Clin. Pathol., 1966.

[7]A. Reiss, A. Samide, G. Ciobanu, and I. Dăbuleanu, "SYNTHESIS , SPECTRAL CHARACTERIZATION AND THERMAL BEHAVIOUR OF NEW METAL ( II ) COMPLEXES WITH SCHIFF BASE DERIVED FROM AMOXICILLIN," vol. 3, pp. 192-194, 2015.

[8]W. H. Mahmoud, M. M. Omar, Y. M. Ahmed, and G. G. Mohamed, "Transition metal complexes of Schiff base ligand based on 4,6-diacetyl resorcinol," Appl. Organomet. Chem., vol. 34, no. 4, pp. 1-20, 2020.

[9]K. Singh, Y. Kumar, P. Puri, and C. Sharma, "Antimicrobial , spectral and thermal studies of divalent cobalt, nickel , copper and zinc complexes with triazole Schiff bases," Arab. J. Chem., no. January, 2013.

[10]J. A. Shaikh, "Synthesis, Spectral Characterization and X - Ray Diffraction studies of some Pd (II) Complexes with Schiff bases," vol. 17, no. 3, pp. 272-280, 2014. 
[11]K. Singh, Y. Kumar, P. Puri, and G. Singh, "Spectroscopic , Thermal , and Antimicrobial Studies of Co (II ), Ni ( II ), Cu ( II ), and Zn ( II ) Complexes Derived from Bidentate Ligands Containing N and S Donor Atoms," no. November, 2012.

[12]B. Sinha and S. Saha, "Imidazolium lonic Liquid- Supported Schiff Base and Its Transition Metal Complexes: Synthesis , Physicochemical Characterization and Exploration of Antimicrobial Activities," pp. 117.

[13]S. H. Mahdi and L. K. A. Karem, "Synthesis, Spectral and Biochemical Studies of New Complexes of Mixed Ligand Schiff Base and Anthranilic Acid," 2018.

[14]F. Y. Waddai, E. K. Kareem, and S. A. Hussain, "Synthesis, Spectral Characterization and Antimicrobial Activity of Some Transition Metal Complexes with New Schiff Base Ligand (BDABI )," 2018.

[15]T. Nadu and T. Nadu, "Synthesis and Characterisation of Transition Metal Complexes with new Schiff base LigandDepartment of Chemistry, HKRH College (Autonomous), Uthamapalayam-625533, Tamil Nadu, India. Department of Chemistry, The Madura College (Autonomous), Madurai -625011," pp. 39-53, 2017.

[16]M. N. A. Al-jibouri, S. A. H. Al-ameri, and W. M. Al-jibouri, "Spectroscopic study of the effect of a new metal chelate on the stability of PVC," J. Assoc. Arab Univ. Basic Appl. Sci., vol. 14, no. 1, pp. 67-74, 2013.

[17]S. Base and D. From, "SYNTHESIS AND CHARACTERIZATION OF SOME METAL COMPLEXES OF A," vol. 16, no. 1, pp. 53-64, 2002.

[18]P. Tyagi, M. Tyagi, S. Agrawal, S. Chandra, H. Ojha, and M. Pathak, "Synthesis, characterization of 1,2,4triazole Schiff base derived 3d-metal complexes: Induces cytotoxicity in HepG2, MCF-7 cell line, BSA binding fluorescence and DFT study," SAA, no. December 2017, 2016.

[19]M. U. Rehman, M. Arif, M. Imran, and M. Farooq, "Synthesis, Characterization and Antimicrobial Properties of Mannich Base Cyclization Derivatives of Benzimidazole and Their Metal Complexes," vol. 4, no. 1, pp. 10$21,2014$.

[20]S. Hossain, "Synthesis, Spectral and Thermal Characterization of Cu (II) Complexes with Two New Schiff Base Ligand towards Potential Biological Application Synthesis, Spectral and Thermal Characterization of $\mathrm{Cu}$ ( II ) Complexes with Two New Schiff Base Ligand towards Potential Biological Application," no. August, 2017.

[21] R. S. Joseyphus and M. S. Nair, "Antibacterial and Antifungal Studies on Some Schiff Base Complexes of Zinc (II),,",22 Jun 2018.

[22]S. A. H. Elbohy, "Synthesis and Electrochemical Studies of Some Metal Complexes with Phosphorus Schiff Base Ligand," vol. 8,.pp. 12387-12401,2013. [23]M. S. Nair, D. Arish, and R. S. Joseyphus, "Synthesis, characterization, antifungal, antibacterial and DNA cleavage studies of some heterocyclic Schiff base metal complexes," J. Saudi Chem. Soc., vol. 16, no. 1, pp. 83-88, 2012.

[24]J. Sawai et al., "Low-temperature growth and properties of ZnO nanowires," Appl. Surf. Sci., 2010. 
[25]J. Devi, S. Devi, and A. Kumar, "Synthesis, antibacterial evaluation and QSAR analysis of Schiff base complexes derived from [2,2'-(ethylenedioxy)bislJethylamine)] and aromatic aldehydes," pp. 932-947, 2016.

[26]R. S. Hebbar, A. M. Isloor, and A. F. Ismail, Chapter 12 - Contact Angle Measurements. Elsevier B.V., 2017.

[27]M. Hamdani, R. N. Singh, and P. Chartier, "Co 304 and Co- Based Spinel Oxides Bifunctional Oxygen Electrodes," vol. 5, pp. 556-577, 2010.

[28]M. Cohen, Elements of X-RAY DIFFRACTION. .

[29]Y. M. Ahmed, W. H. Mahmoud, M. M. Omar, and G. G. Mohamed, "Synthesis, Characterization and Biological Activity of Transition Metals Schiff Base Complexes Derived from 4,6-Diacetylresorcinol and 1,8Naphthalenediamine," J. Inorg. Organomet. Polym. Mater., no. 0123456789, 2021.

[30]Y. M. Ahmed, M. M. Omar, and G. G. Mohamed, "Synthesis, spectroscopic characterization, and thermal studies of novel Schiff base complexes: theoretical simulation studies on coronavirus (COVID-19) using molecular docking," J. Iran. Chem. Soc., no. 0123456789, 2021.

[31]E. S. Aazam and M. Zaki, "Synthesis and Characterization of Ni ( II )/ Zn ( II ) Metal Complexes Derived from Schiff Base and Ortho - Phenylenediamine: In vitro DNA Binding, Molecular Modeling and RBC Hemolysis," no. li, pp. 610-618, 2020.

\section{Figures}




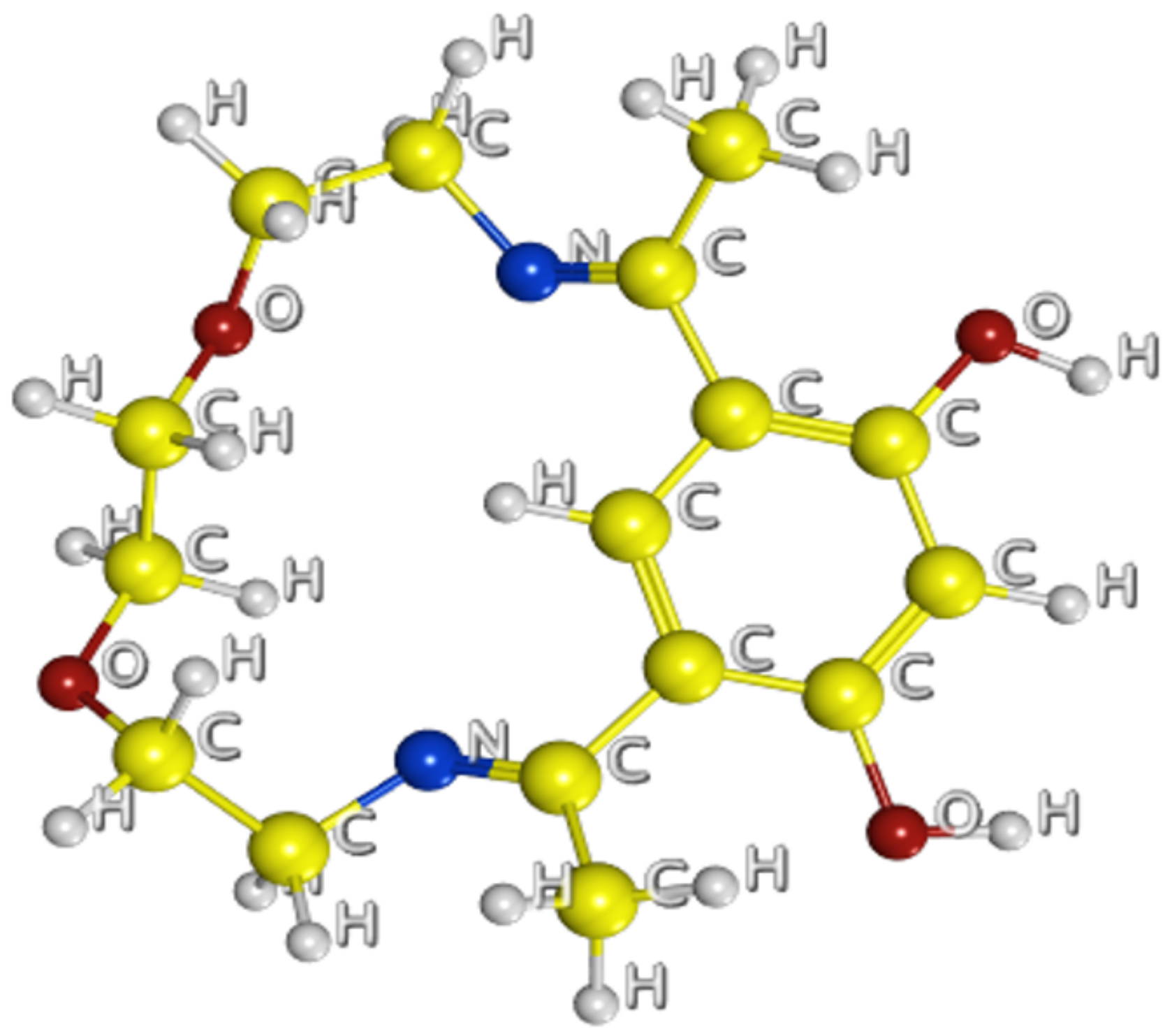

Figure 1

Structure of Schiff base ligand (H2L) illustrating the intra molecular hydrogen bonding. 

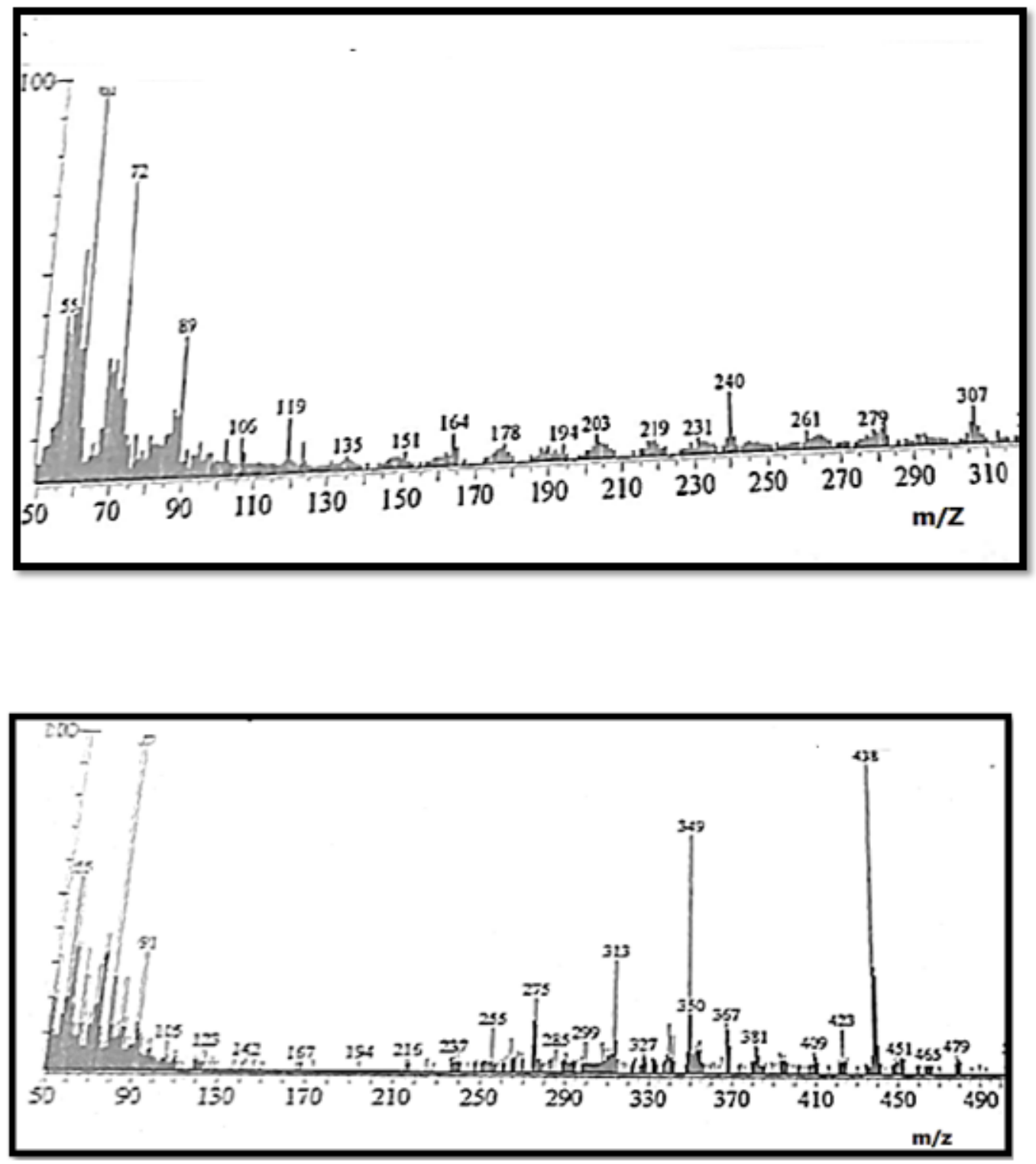

Figure 2

The full scan mass spectra of (a) Schiff base ligand ( $\mathrm{H} 2 \mathrm{~L})$ and $(\mathrm{b})[\mathrm{Zn}(\mathrm{H} 2 \mathrm{~L}) \mathrm{Cl} 2] 2 \mathrm{H} 2 \mathrm{O}$ complex. 

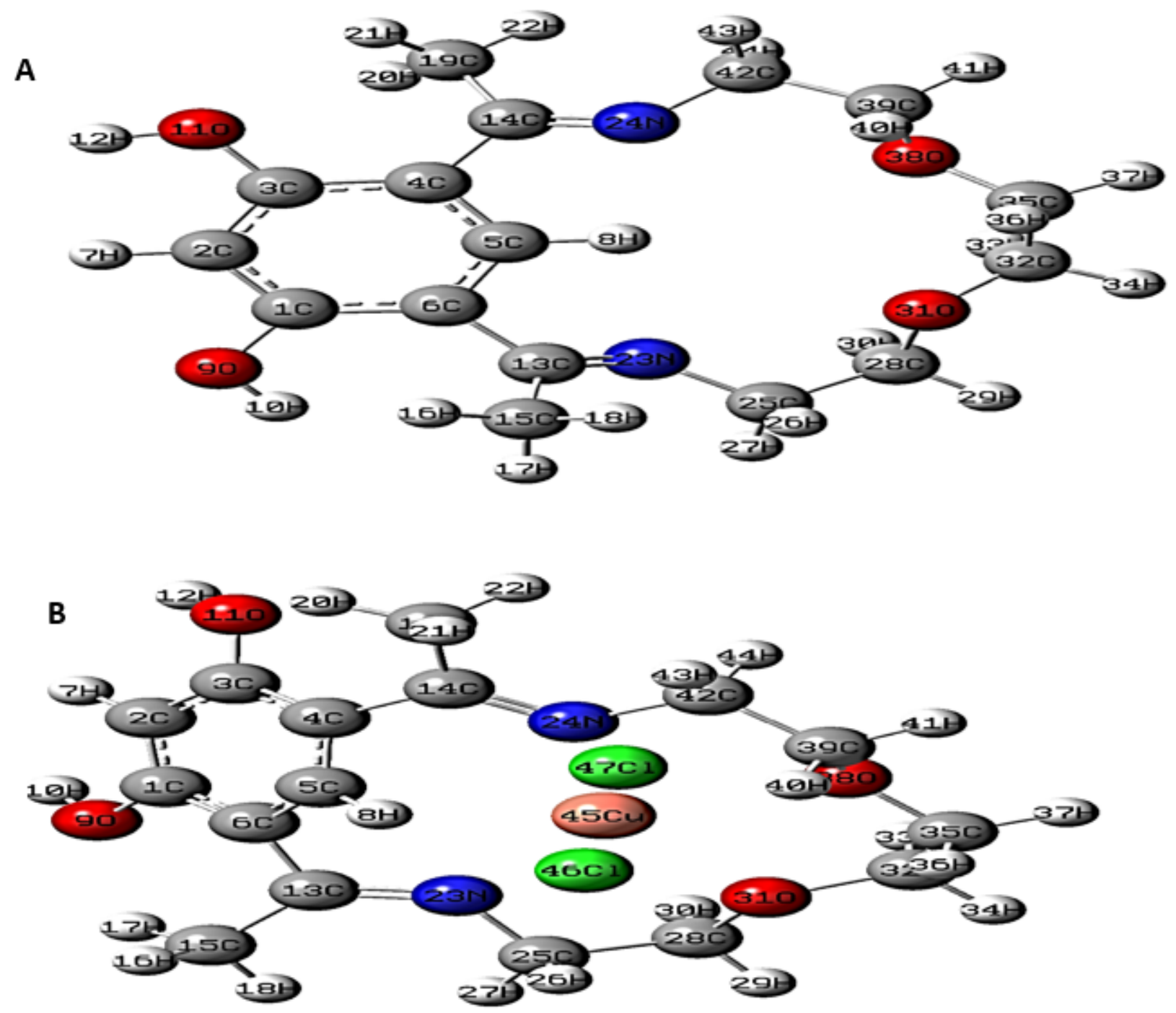

Figure 3

The optimized structures of (a) Schiff base ligand (H2L) and (b) $\mathrm{Cu}(\mathrm{II})$ complex. 

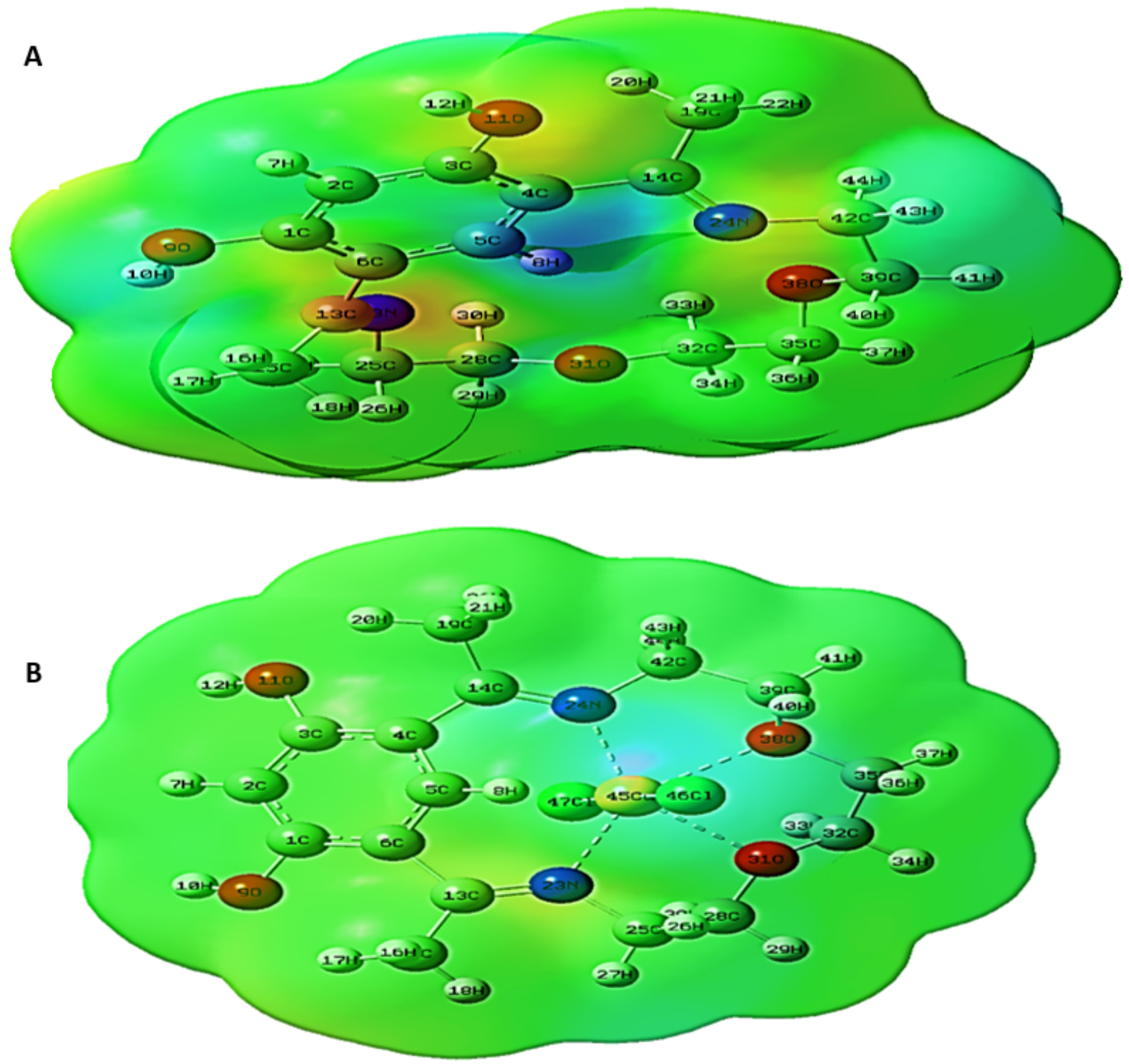

\section{Figure 4}

Molecular electrostatic potential maps of of (a) Schiff base ligand (H2L) and (b) $\mathrm{Cu}(\mathrm{II})$ complex. The electron density isosurface is 0.004 a.u. 
A
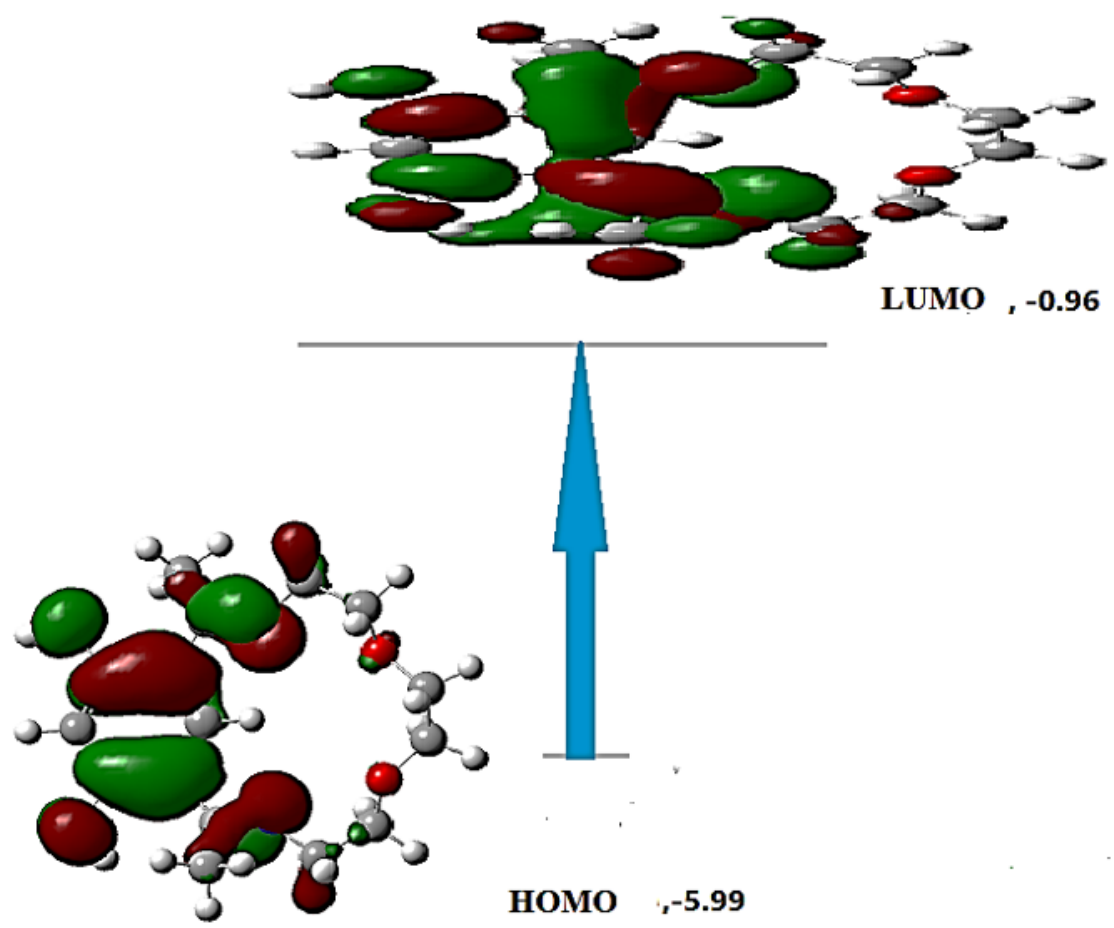

B

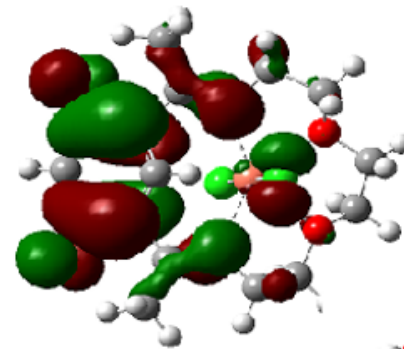

НОМо, -6.41
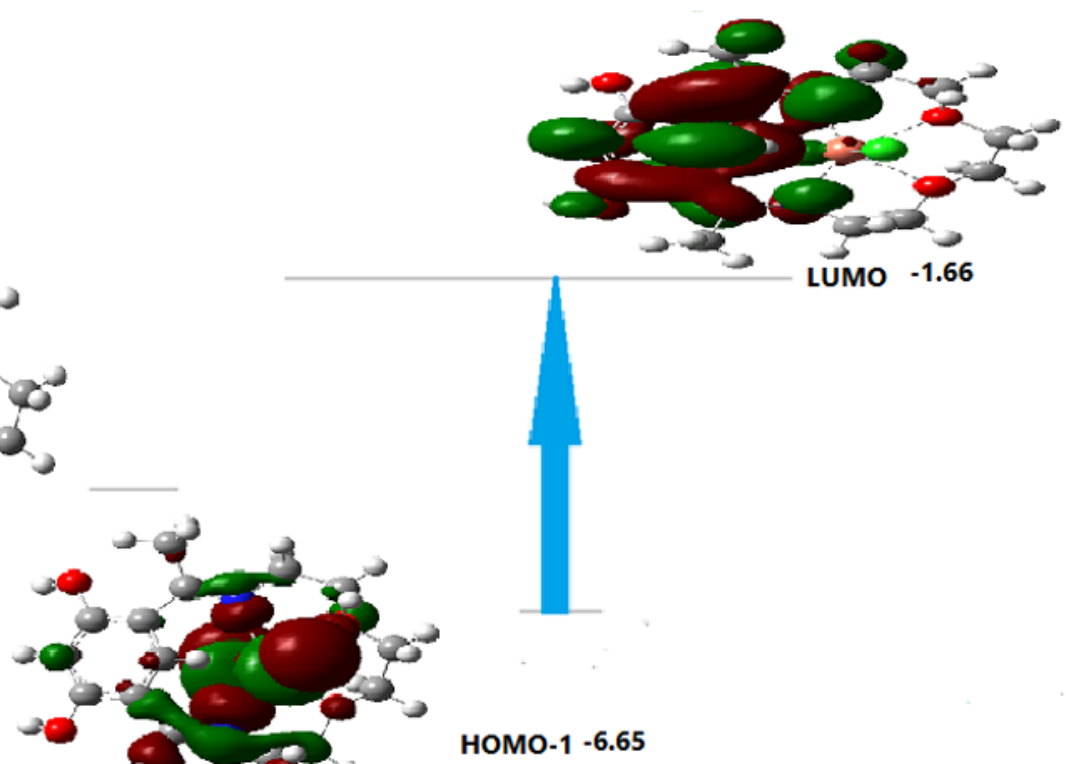

Figure 5

Calculated TD-DFT electronic transitions (in DMF), $\mathrm{H}$ atoms were omitted for clarity (a) Schiff base ligand (H2L) and (b) $\mathrm{Cu}$ (II) complex. 


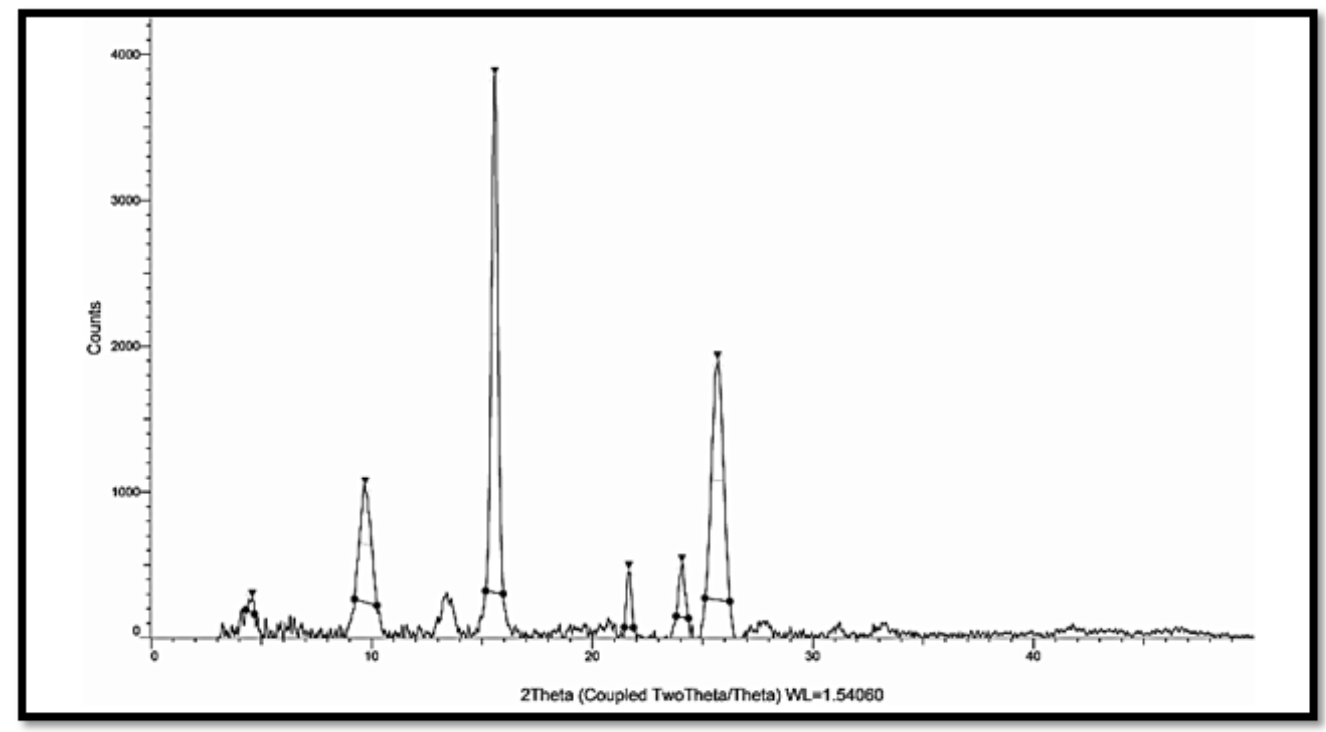

a

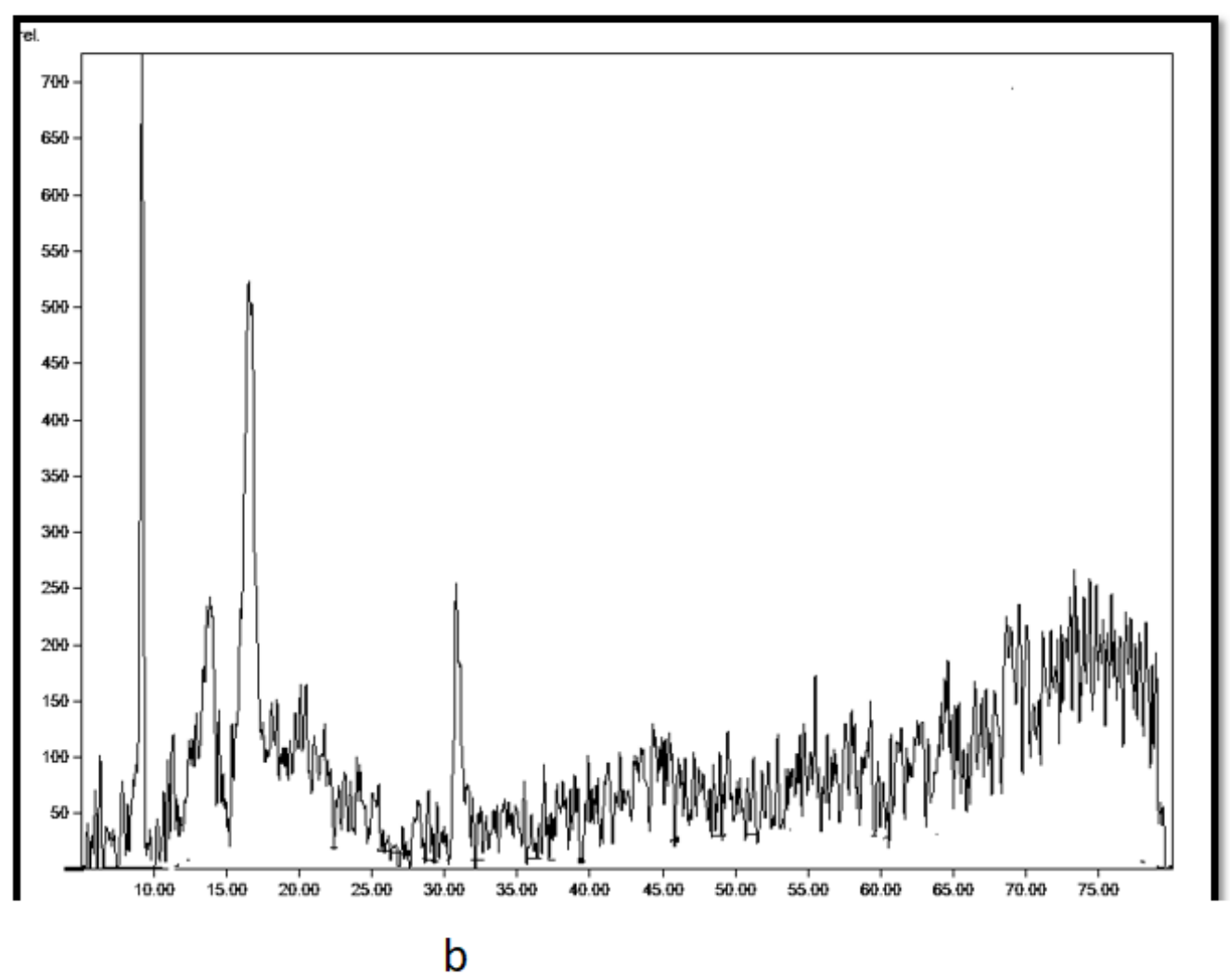

Figure 6

XRD of (A) Schiff base ligand (H2L) and (B) Co(II) complex. 


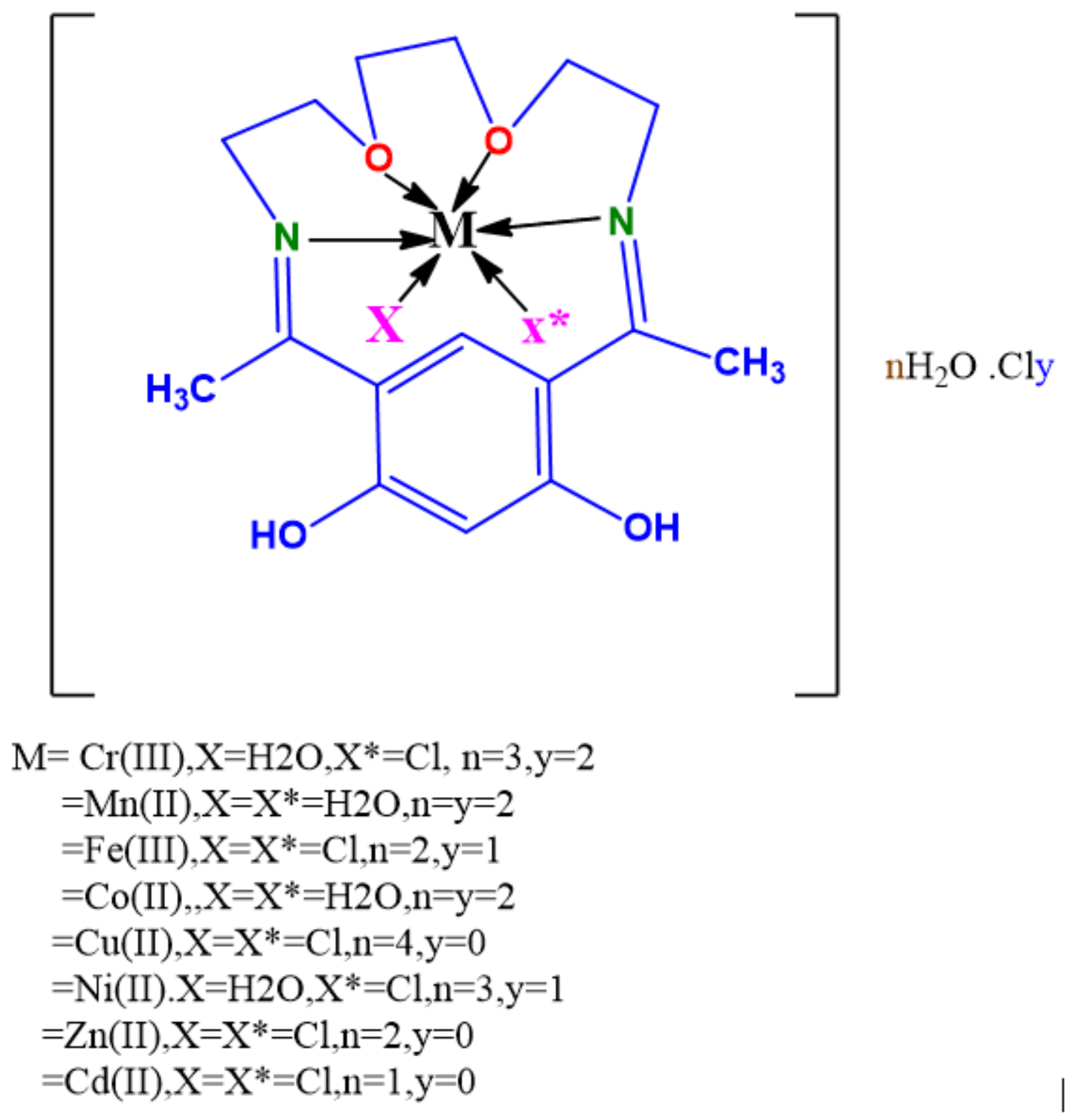

Figure 7

Structures of metal complexes 


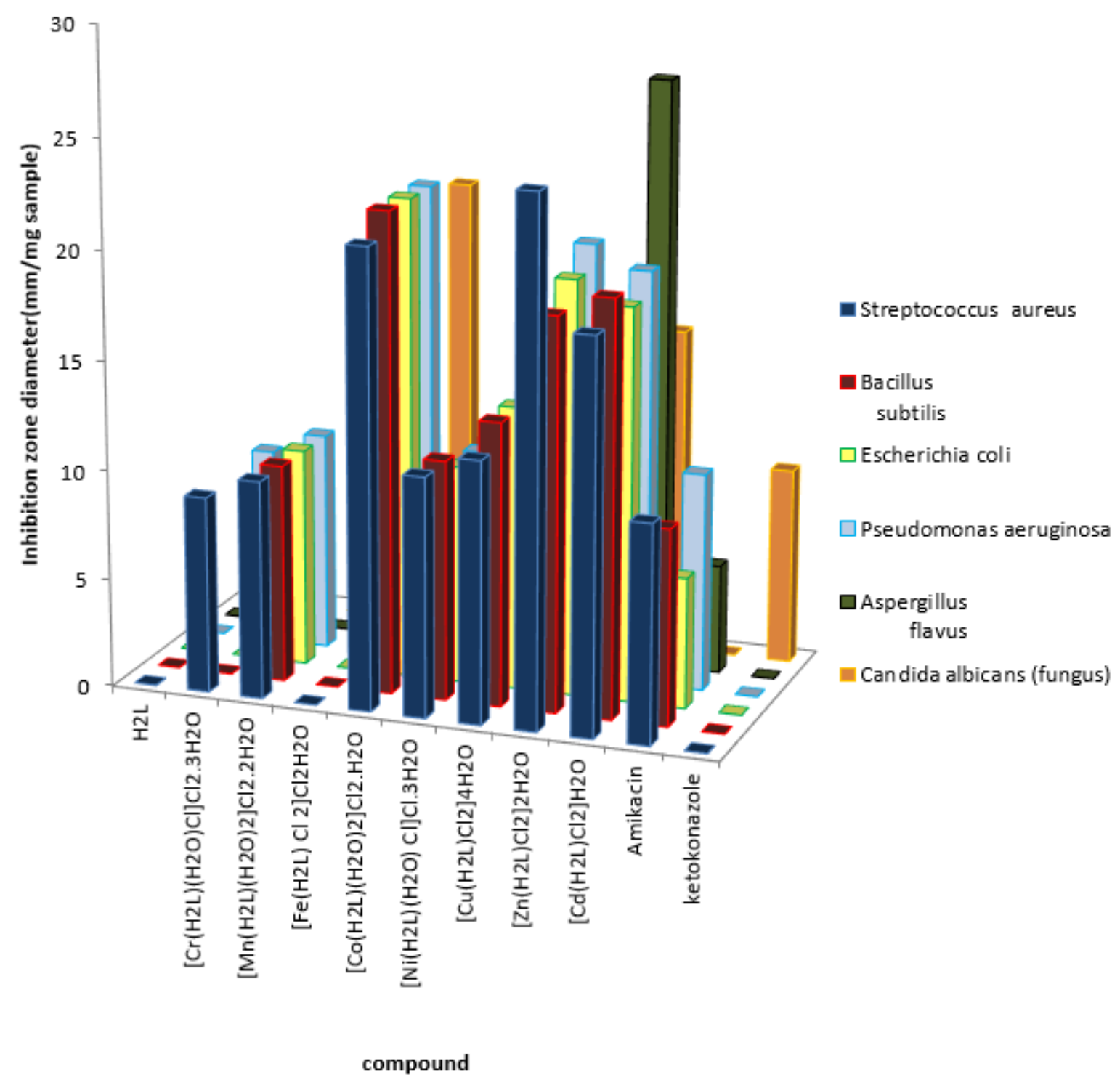

Figure 8

Biological activity of Schiff base ligand and its metal complexes. 


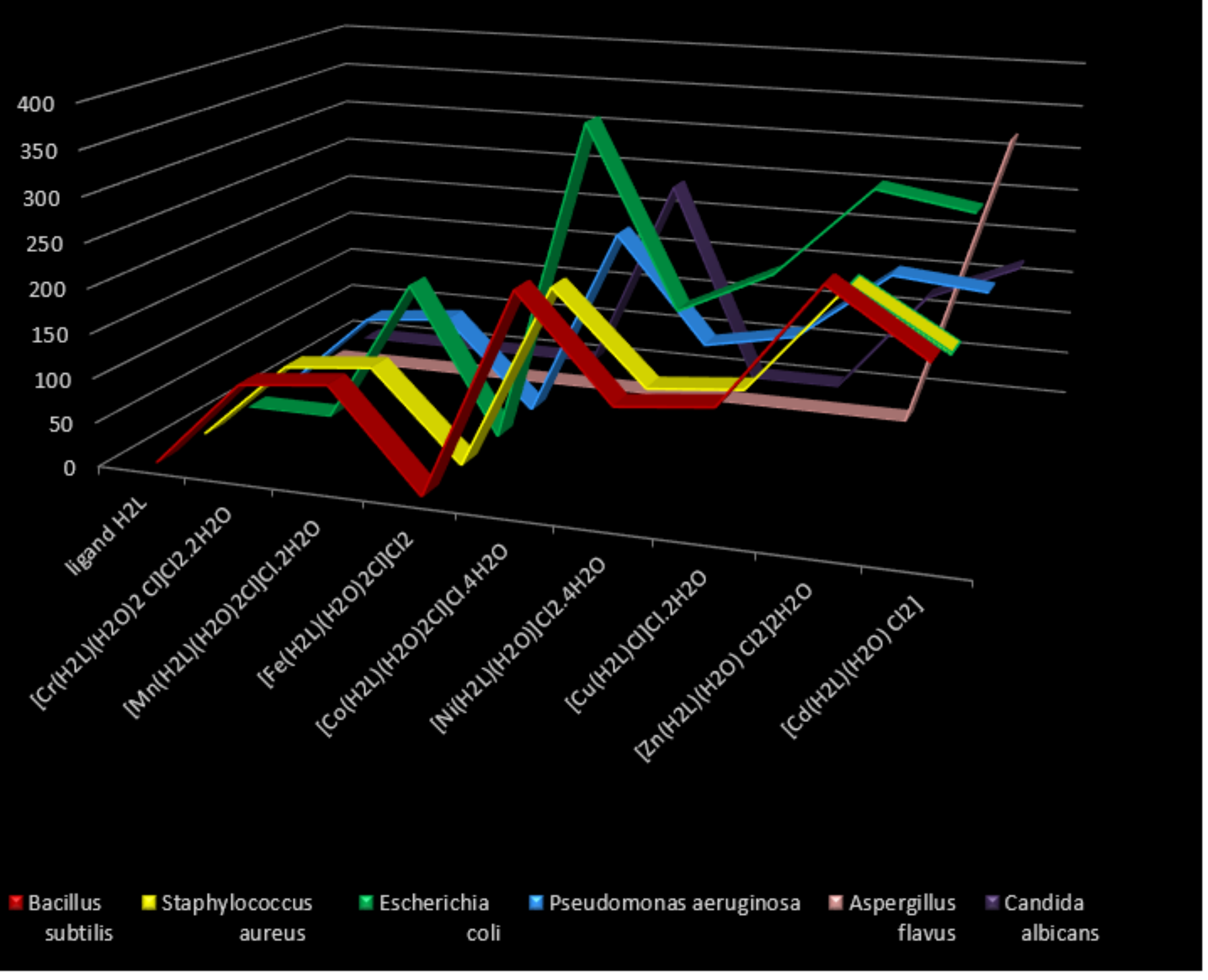

\section{Figure 9}

Activity index values of Schiff base ligand (H2L) and its metal complexes. 


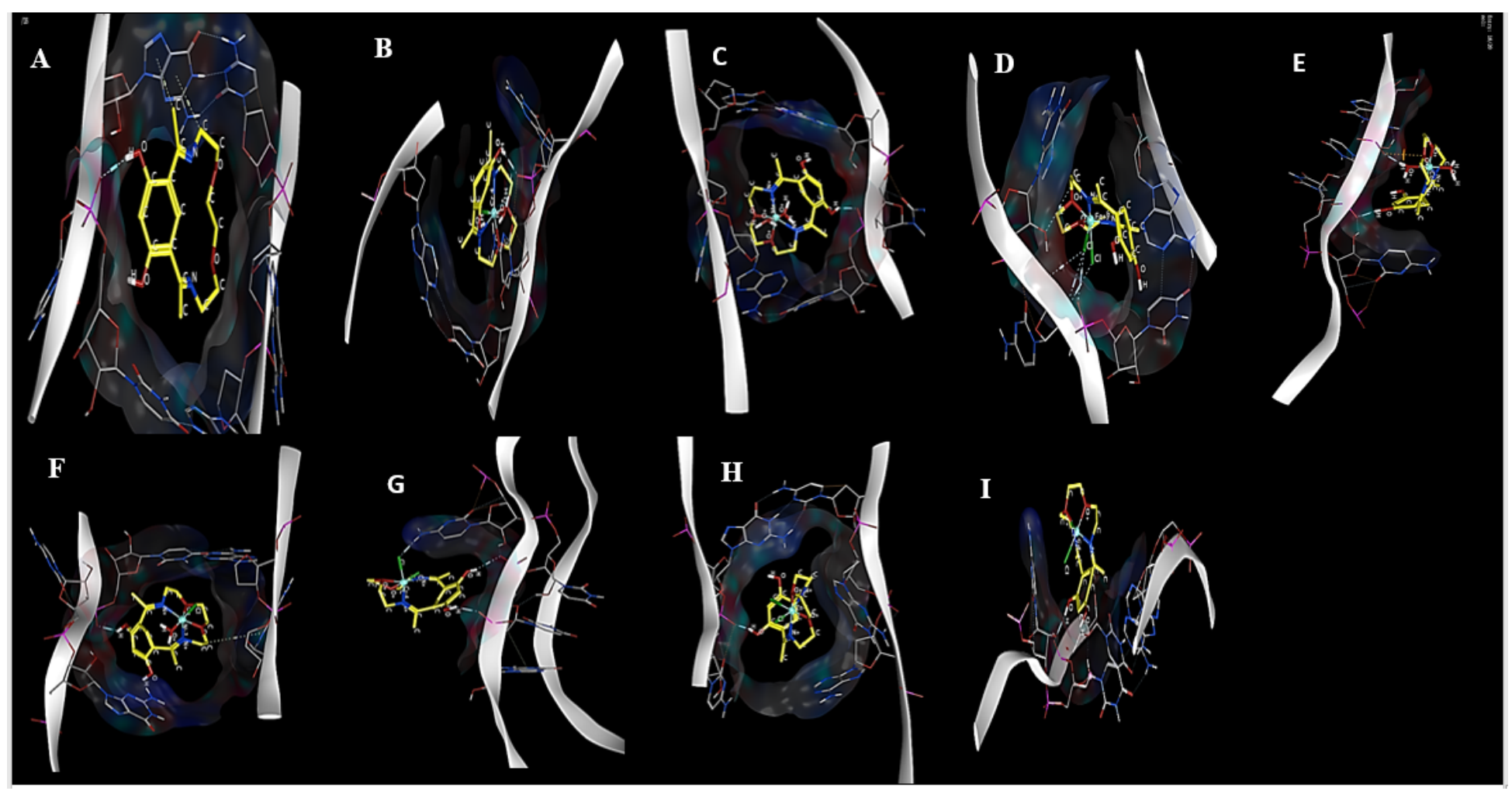

Figure 10

3D Molecular docking simulation studies of the interaction between (A) Schiff base ligand and (B) $\mathrm{Cr}$ (III), (C) $\mathrm{Mn}(\mathrm{II}),(\mathrm{D}) \mathrm{Fe}(\mathrm{III}),(\mathrm{E}) \mathrm{Co}(\mathrm{II})(\mathrm{F}) \mathrm{Ni}(\mathrm{II}),(\mathrm{G}) \mathrm{Cu}(\mathrm{II}),(\mathrm{H}) \mathrm{Zn}(\mathrm{II})$ and (I) $\mathrm{Cd}(\mathrm{II})$ with the active site of the receptor of PDB ID: 6NE0.

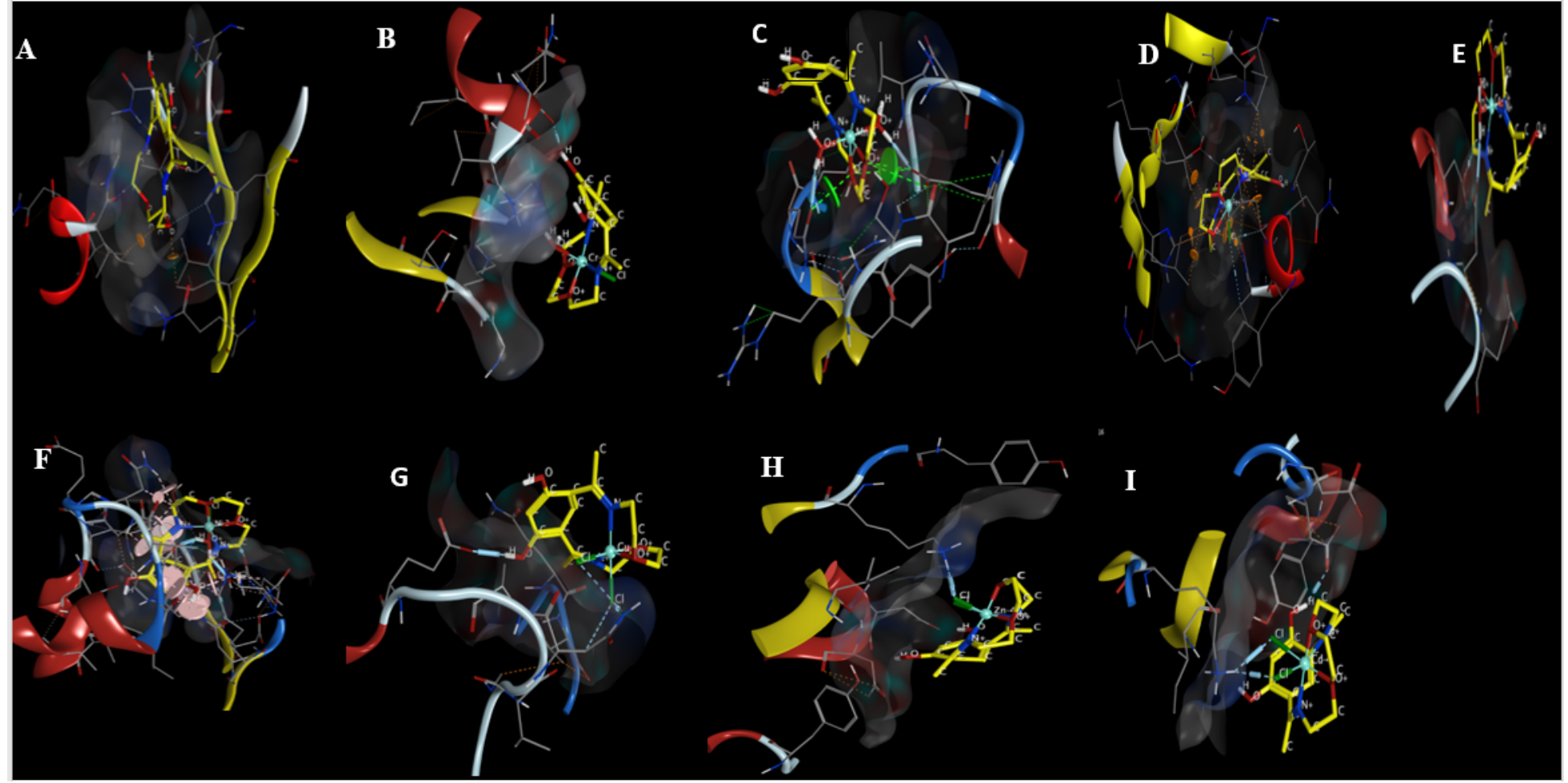

Figure 11 
3D Molecular docking simulation studies of the interaction between (A) Schiff base ligand and (B) $\mathrm{Cr}(\mathrm{III}),(\mathrm{C})$ $\mathrm{Mn}(\mathrm{II}),(\mathrm{D}) \mathrm{Fe}(\mathrm{III}),(\mathrm{E}) \mathrm{Co}(\mathrm{II})(\mathrm{F}) \mathrm{Ni}(\mathrm{II}),(\mathrm{G}) \mathrm{Cu}(\mathrm{II}),(\mathrm{H}) \mathrm{Zn}(\mathrm{II})$ and (I) $\mathrm{Cd}(\mathrm{II})$ with the active site of the receptor of PDB ID: 6iyo. 